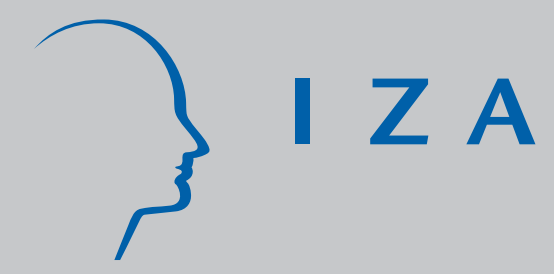

IZADP No. 1798

Structural Reforms and the Exchange Rate Regime:

A Panel Analysis for the World versus OECD Countries

Ansgar Belke

Bernhard Herz

Lukas Vogel

October 2005 


\title{
Structural Reforms and the Exchange Rate Regime: A Panel Analysis for the World versus OECD Countries
}

\author{
Ansgar Belke \\ University of Hohenheim \\ and IZA Bonn
}

Bernhard Herz

University of Bayreuth

Lukas Vogel

University of Bayreuth

\section{Discussion Paper No. 1798 \\ October 2005}

\author{
IZA \\ P.O. Box 7240 \\ 53072 Bonn \\ Germany \\ Phone: +49-228-3894-0 \\ Fax: +49-228-3894-180 \\ Email: iza@iza.org
}

Any opinions expressed here are those of the author(s) and not those of the institute. Research disseminated by IZA may include views on policy, but the institute itself takes no institutional policy positions.

The Institute for the Study of Labor (IZA) in Bonn is a local and virtual international research center and a place of communication between science, politics and business. IZA is an independent nonprofit company supported by Deutsche Post World Net. The center is associated with the University of Bonn and offers a stimulating research environment through its research networks, research support, and visitors and doctoral programs. IZA engages in (i) original and internationally competitive research in all fields of labor economics, (ii) development of policy concepts, and (iii) dissemination of research results and concepts to the interested public.

IZA Discussion Papers often represent preliminary work and are circulated to encourage discussion. Citation of such a paper should account for its provisional character. A revised version may be available directly from the author. 


\section{ABSTRACT}

\section{Structural Reforms and the Exchange Rate Regime: A Panel Analysis for the World versus OECD Countries}

We test the significance of the relationship between the exchange rate regime and the degree of structural reforms by estimating panel regressions for a world and an OECD country sample. The empirical results suggest a positive correlation between on the one side the adoption of an exchange rate rule and on the other side overall structural reforms as well as reforms in the money and banking sector in the broad country sample. For government size and for market regulation, we do not find any robust significant effect, however. The results do not confirm the main implication of Calmfors-type models, namely a higher degree of reforms under monetary policy autonomy. They corroborate conditional policy convergence and, partly, that limiting monetary policy autonomy fosters structural reforms.

JEL Classification: D78, E52, E61

Keywords: exchange rates, monetary policy regime, liberalisation, panel data, political economy of reform

Corresponding author:

Ansgar Belke

Department of Economics

University of Hohenheim

70593 Stuttgart

Germany

Email: belke@uni-hohenheim.de

\footnotetext{
* We would like to thank Eduard Hochreiter for helpful comments and suggestions on an earlier version of this paper. We gratefully acknowledge the hospitality of the Oesterreichische Nationalbank (OeNB) where the first author was a visiting researcher while parts of this paper were written. For delivery of data we are grateful to Stefan Pitlik and Andreas Freytag.
} 


\section{Introduction}

The pressing problem of unemployment and the choice of the appropriate monetary policy strategy are crucial challenges in current academic and political debates. Although both issues are usually connected in public, the academic discussion had neglected, until the mid-nineties, to provide rational arguments for such an interrelation. Until then, the incentives and disincentives for labor, product and financial market reforms and liberalization on the one side and the benefits and costs of monetary policy rules on the other side had typically been analyzed in isolation.

The pros and cons of different monetary policy strategies are usually investigated in the framework of Barro and Gordon (1983, 1983a) and Kydland and Prescott (1977). Both contributions focus on the time inconsistency of discretionary monetary policy (which presupposes monetary policy autonomy) and compare the efficiency of alternative monetary policy rules with the potential losses due to the inflexibility of rules under exogenous shocks. As possible solutions to the trade-off between the time-inconsistency problem of discretionary monetary policy and the inflexibility of rule-based monetary policy, various flexible rules have been proposed. Prominent examples of such limitations of policy autonomy are feedback-rules in connection with distinct commitment technologies, e.g. the independence of central banks or incentive schemes for central bankers (Walsh, 1995; Persson and Tabellini, 1993; Svensson, 1997).

However, the first-best solution to this problem is to remove labor market rigidities, the fundamental cause of high structural unemployment (Svensson, 1997: 104, 109; Duval and Elmeskov, 2005: 5). ${ }^{1}$ Yet, such a proposal could be regarded as rather naive from a public choice perspective which emphasizes that labor market institutions, as an out- 
come of rational political choice, have to be implemented in the loss function of politicians. In this paper, we argue that the design of labor market institutions can be interpreted as the result of utility maximizing political decisions. Therefore, it appears useful to augment the time-inconsistency models by an explicit consideration of labor market reforms.

Cross-country event studies are one approach to empirically examine the impact of monetary policy strategies on the degree of economic reform. There are severe limitations, however. The U.S., e.g., are a monetary union with labor market institutions that encourage a low natural rate of unemployment. The EMS commitment was extremely helpful in fostering the reform process in the Netherlands and Denmark. The same holds for Austria under the DM peg (Hochreiter and Tavlas, 2005). In contrast, the U.K. and New Zealand experienced extensive labor market reforms without adhering to an international exchange rate arrangement. Hence, we choose an econometric analysis for a large sample of countries. Thereby, we go beyond the EMU case studies by van Poeck and Borghijs (2001), Bertola and Boeri (2001), and IMF (2004) which are rare examples of empirical investigations in this field. ${ }^{2}$

The remainder of the paper is structured as follows. Section 2 discusses the main arguments concerning the relationship between monetary policy autonomy and structural reforms in open economies. We also present a simple stylized monetary model of employment and reform effort. Section 3 derives the analytical results from the benchmark model. Finally, we also obtain testable hypotheses concerning the impact of exchange rate flexibility on reforms. Panel estimates on the relationship between the exchange rate regime and the degree of reforms are presented in section 4 . The regressions include a set of additional variables and extensive robustness checks. Section 5 concludes. 


\section{Theory}

\subsection{Conflicting views on the relation between the degree of monetary policy autonomy and structural reforms}

The discussion of the relation between the degree of monetary policy autonomy and structural reforms is characterized by a wide spectrum of conflicting views. We start with a sketch of the literature on monetary policy autonomy and reforms and refer to a prominent example of the loss of monetary autonomy, i.e. the irrevocable fixing of exchange rates under European Monetary Union (EMU). In the run-up to EMU a number of studies tried to assess the incentive effects of alternative monetary policy strategies on labor market reforms. According to the proponents of a liberal view, EMU, as a classical variant of a rule-based monetary policy, should have a disciplinary impact on national labor markets. ${ }^{3}$ In the first place, EMU enhances the credibility of monetary policy and thereby lowers inflation expectations. Negative employment effects as a result of (too) high wage claims can no longer be accommodated by discretionary monetary policy. The responsibility of wage setters for unemployment increases significantly, because they no longer negotiate about nominal wage but real wage growth. The responsibility for existing unemployment is more transparently assigned to the parties which negotiate the relative price of labor. In contrast, autonomous discretionary monetary policy makes it more difficult to remove market rigidities because there is still the option to solve or at least to shift the unemployment problem onto third parties. i.e. to an expansionary monetary policy.

Insofar as the single currency increases transparency, the costs of structural rigidities, as reflected in relative prices, become more evident. Lower trading costs and higher transparency jointly tend to foster competition in goods markets, which in turn reduces the 
available product market rents . If these rents are smaller, the incentive to resist reforms that prevent such rents to be captured are smaller as well.

Overall, the incentives for extensive reforms of goods, labor, and capital markets increase under a regime of irrevocably fixed exchange rates. ${ }^{4}$ If changes in monetary policy and the nominal exchange rate are not available, and if labor is immobile as is the case in most parts of the Euro area, there is no other option than to undertake reforms in order to facilitate the market-based adjustment to shocks. Hence, credible currency pegging has often been interpreted as a version of Mrs. Thatcher's There-Is-No-Alternative (TINA) strategy. ${ }^{5}$ In this paper, we intend to generalize this striking TINA argument empirically and extend it to countries beyond the narrow focus of the Euro area, which is what e.g. Duval and Elmeskov (2005) concentrate on.

However, there are also important arguments against a positive impact of monetary rules on economic reform. First, based on OECD macro model simulations it was often argued with respect to EMU that the so-called up-front costs of structural reforms may be larger within a currency union. This holds especially in large, relatively closed countries for which changes in the nominal exchange rate are not so effective in alleviating the necessary "crowding-in" effect. Removing restrictions in financial markets tend to stimulate demand more than labor market reforms and hence allow an easier and quicker "crowding-in" of reforms (Bean, 1998, Duval and Elmeskov, 2005: 6-7, SaintPaul and Bentolila, 2000). Hence, the prior in this case would be that rule-based monetary policy regimes like, e.g., EMU, lead to more reforms in the financial market than in the labor market. 
Second, Calmfors (1997) and Sibert and Sutherland (1997) argue that one should not expect from monetary policy with its mainly short-run real economy effects to diminish structural unemployment significantly. Hence, rule-based monetary policy does not necessarily imply more reform pressure. In the same line, empirical analysis indicates that the capability of exchange rates to absorb asymmetric shocks to labor and goods markets is rather low. Hence, flexibility of exchange rates does not seem to be a good substitute for reforms and the degree of reforms is not necessarily higher under fixed exchange rates (Belke and Gros, 1999).

Third, some analysts support the view that rule-based monetary policy, at least if it takes effect through entering a fixed exchange rate regime, has no disciplinary effects on the wage setting process, but leads to centralization processes and strengthens the incentives to claim high wages on the part of unions. Fourth, the limited evidence of price structure convergence for instance among core-EMS countries as compared with other countries speaks against any significant impact of credible exchange rate stabilization on product market competition. Hence, there are still product market rents to be captured and there will still be resistance to reforms (Haffner et al., 2000). From these introductory remarks it should be clear that the implementation of specific monetary policy rules significantly changes the conditions for and the efficiency of structural reforms (Calmfors, 1997, 1998; Grüner and Hefeker, 1996). Let us assume for the moment that the main aim of labor market, product market and fiscal reforms is to lower structural unemployment and that the term monetary policy rule is used in a more general fashion, i.e. that it comprises both monetary and exchange rate policy. The assessment of different monetary policy rules from the employment perspective is then dependent on their specific impact on the implementation of market-oriented reforms: do 
they trigger or hinder market reforms? Moreover, it is decisive whether autonomous discretionary policy is able to settle the dispute between interest groups and to support the efficiency of structural reforms.

\subsection{A benchmark model}

In the following, we critically discuss the widely held view that the effects of changes in the monetary regime on the probability of market-oriented reforms are not predictable and speculative in the light of the Lucas critique. We endogenize market liberalization in a Barro-Gordon-framework and focus on the long-run effects of reform. ${ }^{6}$ The loss function of the policy maker includes as bads not only inflation and unemployment but also structural reforms. These include reforms of the labor market itself and of other areas relevant to the labor market, such as the goods markets, the social security system and fiscal policy as e.g. proxied by the Fraser Institute Economic Freedom of the World index (Gwartney and Lawson, 2003; Gwartney et al., 2003). In the following, we denote these types of reforms as market-oriented reforms.

In political economy models it is generally assumed that politicians suffer welfare losses when implementing market-oriented reforms for two reasons. First, reforms tend to reduce at least in the short run the wages of employed insiders, who are frequently organized in powerful syndicates (trade unions) and who are the relevant political majority for re-electing the incumbent government. There is wide evidence that outsiders are generally compensated by active labor market policies and public transfers. Marketoriented reforms can be best interpreted as a downward shift of the seminal wage setting curve popularized by Layard, Jackman and Nickell (1994) and Lindbeck (1992) towards the employment axis. This shift can be explained by the same factors that are emphasized by insider-outsider theories as arguments for the specific slope of the wage setting 
curve. A reform could, e.g., reduce the period in which the unemployed receive unemployment benefits, which is a highly significant determinant of the diverging unemployment rates in OECD countries (Calmfors, 1998; Nickell, 1997). The real reservation wage of the unemployed would drop proportionally to the degree of reforms. ${ }^{7}$

Second, an intrinsic welfare-enhancing value is attached to existing labor market regulations. They diminish the susceptibility of the employed to shocks (protection against unlawful dismissal) and, as in the case of unemployment benefits, inherently bear an insurance character (Berthold and Fehn, 1996, Calmfors, 1998, Saint-Paul, 1993, 1996).

In order to account for these considerations, we augment the usual Lucas type unemployment equation and the hypothesis of rational expectations by an additional condition: the natural unemployment is linearly dependent on the chosen degree of marketoriented reforms. We distinguish two scenarios, an autonomous and discretionary monetary policy and a non-autonomous, rule-based monetary policy.

In order to interpret the degree of market-oriented reforms as a rational political choice of politicians, the common loss function $L$ is augmented as follows:

$$
\text { (1) } L=1 / 2\left[(u-\hat{u})^{2}+\lambda(\pi-\hat{\pi})^{2}+\gamma r^{2}\right] \text {, }
$$

where $u$ is the actual unemployment, $\hat{u}$ is the unemployment target, $\pi$ is the actual inflation rate, $\hat{\pi}$ is the inflation target, $r$ corresponds to the actual degree of marketoriented reforms, $\lambda$ is the weight of the deviation of inflation from its target and $\gamma$ represents the weight of reforms in the loss function $(r \geq 0)$. To simplify the analysis, we assume separability of the loss function, although there are cases where the marginal utility of a reform depends on the level of unemployment (Saint-Paul, 1996).

Unemployment is determined by an expectation augmented Phillips-curve: 
(2) $u=u^{*}-\beta\left(\pi-\pi^{e}\right)+\varepsilon$, with

(3) $\pi^{e}=E(\pi)$.

$u^{*}$ is the natural rate of unemployment, $\pi^{e}$ is the rationally expected inflation rate and $\varepsilon$ is a stochastic i.i.d. shock. The parameter $\beta$ characterizes the extent of nominal wage rigidities, i.e. the intensity with which real wages react to non-anticipated changes in the price level. If the government reduces the inflation rate by one percentage point per year it has to accept $\beta$ additional percentage points of unemployment. Therefore, $\beta$ can be considered as the sacrifice ratio (Layard, Jackman and Nickell, 1994: 84-85).

An additional significant deviation from the standard Barro-Gordon-model is the assumption that the natural rate of unemployment depends on the chosen degree of market-oriented reform $r$ in a linear fashion:

(4) $u^{*}=\tilde{u}-\delta r$.

$\tilde{u}$ is the natural unemployment in the absence market-oriented reforms $(r=0)$ and $\delta$ represents the marginal effectiveness of structural reforms with respect to the reduction of structural unemployment.

In the following, we analyze a one-period game, in which politicians determine labor market institutions and monetary policy. Decisions on the labor market institutions are made before stochastic exogenous shocks occur. They take the inflation-reaction function into consideration. Once the decision on the labor market arrangement is made, it is irreversible. Monetary policy is characterized by more flexibility. Under flexible exchange rates, the central bank is able to react to stochastic shocks within a period and can stabilize such shocks. 


\section{Results from the benchmark model}

\subsection{Credible commitment to a strict monetary policy rule}

In order to develop a reference scenario, it is assumed that national politicians can be committed to a credible and optimal monetary policy rule. This could be attained either by membership in a currency union with an inflation-averse central bank, or by entering a credible exchange rate peg (Calmfors 1998: 29). ${ }^{8}$ The optimization problem consists of simultaneously identifying a monetary policy rule and the degree of market-oriented reforms that minimize the government's loss function. ${ }^{9}$ Which values of $\pi, \pi^{e}$ and $r$ minimize equation (1) taking into account equation (2) and (4) under the assumption of rational expectations?

If the natural and the targeted level of unemployment $\left(u^{*}=\hat{u}\right)$ are equal, the politicians choose the same inflation rate as in the case of the optimal monetary policy rule (Barro and Gordon, 1983a: 597; Svensson, 1997: $101 \mathrm{ff}$.). The optimization must therefore be carried out with respect to the restriction $u^{*}=\hat{u}$. Taking rational expectations into account and substituting $\pi^{e}$ the optimal monetary policy rule yields:

$$
\pi=\hat{\pi}+\left(\beta /\left(\lambda+\beta^{2}\right)\right) \varepsilon
$$

In the optimum, the inflation target $\hat{\pi}$ is pursued. To stabilize exogenous shocks, however, deviations from the inflation target are allowed for.

On average, neglecting the i.i.d. shocks ${ }^{10}$, the degree of reforms amounts to:

(6) $-\delta(u *-\hat{u})+\gamma r=0$

or equivalently to:

(6a) $r^{*}=\delta(\tilde{u}-\hat{u}) /\left(\gamma+\delta^{2}\right)$. 
Equations (6) and (6a) have a number of interesting implications. The degree of marketoriented reforms is chosen so that the marginal utility of a lower equilibrium unemployment (i.e. the deviation from targeted unemployment weighed with the marginal efficiency of structural reforms $\left.-\delta\left(u^{*}-\hat{u}\right)\right)$ is equal to the marginal costs of reforms $(\not r)$. What is the economic intuition behind these results? The degree of structural reforms is positively related to the level of structural unemployment and the deviation of the structural from the politically targeted unemployment respectively $(\delta r * / \delta \tilde{u}>0)$. The degree of structural reforms is nevertheless negatively related to the marginal costs of reforms $\left(\delta r^{*} / \delta \gamma<0\right)$. Simultaneously, the degree of structural reforms is independent of the nominal level of rigidities $\left(\delta r^{*} / \delta \beta=0\right)$. Let us now turn to the analysis of discretionary policy, which is only possible if there is monetary policy autonomy.

\subsection{Autonomy and discretion: time inconsistency of optimal monetary policy}

The empirical literature on the time inconsistency problem of optimal monetary policy shows that it is realistic to model the economic decision process of discretionary monetary policy as a two-stage game. In the first stage, wage contracts are fixed on the basis of expected inflation. Moreover, the degree of market-oriented reforms is determined and exogenous stochastic shocks are realized. In the second stage, monetary policy sets the course in a discretionary way. One reason to suppose a discretionary character of the game is the low probability of successfully implementing credible commitments to an ex ante optimal monetary policy if policy is autonomous and has some leeway.

The optimization approach in our model essentially remains the same as in the commitment case. The equation to determine the optimal inflation rate $\pi^{\text {opt }}$ is unchanged (see eq. (5)). However, the solution is more complicated because in the discretionary 
case it cannot be presupposed that $u^{*}=\hat{u}$. Considering rational expectations and substituting $\pi^{e}$ yields the following monetary reaction function:

(7) $\pi=\hat{\pi}+(\beta / \lambda)(u *-\hat{u})+\left(\beta /\left(\lambda+\beta^{2}\right)\right) \varepsilon$.

In comparison to the commitment case, the additional term $(\beta / \lambda)\left(u^{*}-\hat{u}\right)$ follows from for the time inconsistency problem. Several aspects of this result shed light on the relation between different monetary regimes and labor market reforms. It is significant that the degree of the inflation bias does not only dependent on $\lambda$, the relative weight of the inflation target in the loss function, but also on parameters which - directly or indirectly - are related to labor market reforms. First, there is the dependence on natural unemployment $u^{*}$ which is according to equation (4) directly and negatively influenced by labor market reforms. Second, the sacrifice ratio $\beta$ considerably affects the level of the inflation bias. $^{11}$

In the first stage of the game, politicians decide on the degree of reforms, taken the inflation reaction function as given. They select $r$ in such a way that the expected loss function (1) is minimized under the conditions of equations (2), (4) and (7). In contrast to section 3.1, the reaction function for the inflation rate is directly implemented in the loss function and not added as an additional condition. When fixing the degree of structural reforms $r$ the politicians have to consider that the equilibrium inflation rate depends on the level of natural unemployment. However, the realization of the stochastic shock is not recognized until the ex ante optimal degree of reforms is fixed. Therefore, not only the stochastic part of equation $(7)-\left(\hat{\pi}+(\beta / \lambda)\left(u^{*}-\hat{u}\right)\right)-$ is used. After optimization, the degree of reform is: 
(6b) $r r-\delta(u *-\hat{u})-\frac{\beta^{2} \delta}{\lambda}(u *-\hat{u})=0$

or alternatively after some rearrangement:

(6c) $\quad r^{*}=\frac{\delta\left(\beta^{2}+\lambda\right)}{\delta^{2}\left(\beta^{2}+\lambda\right)+\gamma \lambda}(\tilde{u}-\hat{u})$.

In equation (6b), the marginal utility of lower equilibrium unemployment equals the marginal cost of reform. In comparison to the commitment case, an additional marginal utility component, $-\beta^{2} \delta\left(u^{*}-\hat{u}\right) / \lambda$, is contained. It can be directly related to the increased utility of a smaller inflation bias $(\beta / \lambda)\left(u^{*}-\hat{u}\right)$ which is induced by the implementation of reforms.

Most important in our context, it can be shown that the degree of structural reforms is less in the commitment case than in the case of autonomous and, hence, discretionary monetary policy. For that purpose, the right-hand-side of equation (6c) - the degree of reforms under discretionary policy - and the right-hand-side of equation (6a) - the degree of reforms under commitment - are compared.

(8)

$$
\begin{aligned}
& \frac{\delta\left(\beta^{2}+\lambda\right)}{\delta^{2}\left(\beta^{2}+\lambda\right)+\gamma \lambda}(\tilde{u}-\hat{u})-\frac{\delta}{\left(\gamma+\delta^{2}\right)}(\tilde{u}-\hat{u})= \\
& {\left[\frac{\delta\left(\beta^{2}+\lambda\right)}{\delta^{2}\left(\beta^{2}+\lambda\right)+\gamma \lambda}-\frac{\delta\left(\beta^{2}+\lambda\right)}{\delta^{2}\left(\beta^{2}+\lambda\right)+\gamma\left(\beta^{2}+\lambda\right)}\right](\tilde{u}-\hat{u})>0 ?}
\end{aligned}
$$

Obviously, this inequality is fulfilled because $\gamma\left(\beta^{2}+\lambda\right)$ in the denominator of the second fraction is larger than $\gamma \lambda$ in the denominator of the first fraction. Both fractions only differ by these two parts. The degree of reforms is therefore higher in the case of autonomous policy (discretion) and lower in the case of commitment. 
If monetary policy is autonomous, market-oriented reforms seem to achieve a 'double dividend' since monetary policy is discretionary. First, the reforms reduce -like a rulebased monetary policy - the costs of structural unemployment. Secondly, they lessen equilibrium inflation since they diminish the credibility problem of discretionary monetary policy. The second effect is absent in the case of rule-based monetary policy. By definition rule-based monetary policy does not suffer from a credibility problem. Hence, our central question relates to the correlation between reform intensity and the degree of autonomy of monetary policy, which might be determined to a large degree by the exchange rate regime, at least if the country is small and open (Duval and Elmeskov, 2005: 9 and $23 \mathrm{ff}$. .). We focus on the notion of monetary policy autonomy instead of discretion since we consider it as an important prerequisite of discretionary monetary policy. In this respect, our approach strictly follows Duval and Elmeskov (2005: 25) who measure the loss of autonomy of monetary policy by the degree of participation in any kind of fixed exchange rate agreement.

More specifically, we will test the following hypotheses:

(1) The degree of reforms turns out to be higher in the case of monetary policy autonomy than under a monetary policy rule.

(2) This should be valid not only for labor market reforms but also for complementary reforms in the goods and the financial markets.

(3) However, if the TINA-view of exchange rate fixing as a structural whip is valid, one should expect the contrary, namely a positive impact of a monetary policy rule on the extent of reforms. 
Note that one should not conclude on the basis of our theoretical results that a discretionary policy with a higher equilibrium inflation, a higher degree of reforms and lower unemployment is generally superior to a rule-based monetary policy. A welfare comparison of both alternatives would immediately yield the result that a monetary policy rule is generally superior to discretionary monetary policy (Belke and Kamp, 1999).

Under autonomous and discretionary monetary policy, labor-market reforms turn out to be more trenchant and come out to be more successful for the same reason (as measured by the degree of lowering the structural unemployment rate), simply because they are needed more pressingly. Insofar as a superior (and in the ideal case a perfect) instrument is available for the parallel reduction of the equilibrium inflation rate, namely a strict monetary policy rule, the higher degree of labor-market reforms under discretionary monetary policy only signals a form of overshooting.

\subsection{Extension to the open economy case}

Economic openness generally relates to the share of exports and imports in GDP. A stronger exposure of firms to international competition is often assumed to increase the pressure and the incentives for market-oriented reforms. In open economies, output and employment tend to be highly responsive to price competitiveness and, hence, incentives to undertake reforms are large (see, e.g., Katzenstein, 1985, and Nickell, 2005: 23). However, empirical evidence is not especially supportive of the view that open economies are more likely to liberalize. Although Pitlik and Wirth (2003) report a positive impact of economic openness on market-oriented reforms, Herz and Vogel (2004) and Pitlik (2004) do not find robust significant coefficients of economic openness for their summary indicator. Only the trade policy indicator points to a positive effect of economic openness on liberalization. Similarly, the constitutional requirements of po- 
litical decision-making influence the feasibility of policy changes. However, our theoretical sections 3.1 and 3.2 indicate a possible solution to this puzzle. The key insight is that more open economies are more likely to implement rule-based exchange rate stabilization and, hence, generally implement less reforms. Table 1 illustrates this empirical relation between economic openness and exchange rate policy. Exchange rate flexibility is measured on a scale from 1 (hard peg) to 4 (free float). The average and median statistics indicate that less open economies tend to have relatively flexible exchange rate regimes, whereas very open economies tend to favor currency fixes.

\section{- Table 1 about here -}

We continue to assume that the main aim of reforms is to lower structural unemployment, but use the term monetary policy rule in a more general fashion, i.e. that it comprises both monetary and exchange rate policy. Following this notation, we equate the case of flexible exchange rates with the case of autonomous and discretionary monetary policy and use the notion of a fixed exchange rate system in cases which we originally addressed as rule-based monetary policy. But is this generalization legitimate, i.e. to interpret our model in terms of exchange rate regimes instead of monetary policy regimes?

As a stylized fact, the amount of money in an open economy is not determined autonomously by the central bank but is determined endogenously by the exchange rate regime (see, e.g., Annett, 1993: 25; Krugman and Obstfeld, 2003, chapters 16 and 17). From early political business cycle research it is well-known that especially in the case of small open economies there is little evidence of rational partisan cycles (rational partisan theory RPT), i.e. high and increasing inflation rates under left-wing governments and low and diminishing inflation rates under right-wing regimes. ${ }^{12}$ In the standard lit- 
erature, the failure to establish partisan cycles is generally traced back to the fact that small open economies tend to have fixed exchange rates and, hence, the ability of these countries to exert an ideologically motivated impact on the inflation rate is limited. ${ }^{13}$ If the limited degree of monetary policy autonomy under fixed exchange rates is increased by choosing a flexible exchange rate regime, there is more scope for partisan-oriented monetary policies. Wage negotiating parties tend to anticipate and account for different preferences of political parties only if exchange rates are flexible. Only in this case, incumbent governments are able to manipulate the inflation rate by monetary and exchange rate policies. Hence, higher inflation rates under left-wing governments induced by a dynamic inconsistency problem can only arise, if exchange rates are flexible. ${ }^{14}$

A second argument underpins this view. Assume the existence of an international business cycle. In more open economies partisan considerations that arise at the domestic level are more likely to affect policymakers' incentives to engage in international cooperation. Left-wing governments cannot credibly commit themselves to international cooperation and prefer beggar-thy-neighbor policies so that the inflation bias of leftwing governments even increases in open economies. International cooperation, e.g., by fixed exchange rate arrangements, tends to eliminate the inflation bias via the same mechanism (Lohmann, 1993: 1374 ff.). The final argument in favor of our approach is that the hypothesis of an loss of monetary autonomy under fixed exchange rates rests on the assumption of perfect international capital mobility. This mobility has increased since the start of the 1970s, the beginning of the time period investigated in this paper.

Empirical studies of the rational partisan theory clearly show that - assuming a monetary model of the exchange rate - party-specific trajectories of money growth and inflation rates go along with proportional movements of the exchange rate. For instance, 
left- wing governments are more likely to experience inflation, capital flight, current account deficits and currency devaluation. ${ }^{15}$ Hence, we feel justified to equate a flexible exchange rate system with a regime of autonomous and discretionary monetary policy and a system of fixed exchange rates with a rule-based monetary policy regime. From this point of view, our previous arguments that have been elaborated for the concepts ‘rule-based versus discretionary monetary policy' can be transferred to those of 'fixed versus flexible exchange rate systems' and can be tested empirically in a straightforward fashion.

\section{Empirical analysis}

\subsection{Hypotheses}

In general, we now ask whether a significant positive correlation between exchange rate flexibility and market liberalization results if the usual impact factors like the macro economic environment or political and institutional impediments to economic reforms are controlled for. Hence, we test for a significant coefficient of our measure of exchange rate flexibility in regressions using reform indices as the dependent variable and check for robustness of the results. In accordance with section 3.2, the following hypotheses are expected to hold:

(1) If the view of an overshooting intensity of reforms under monetary policy autonomy is correct, the degree of reforms turns will be higher for more flexible exchange rates, net of other factors.

(2) However, if the TINA-view of exchange rate fixing as a structural whip is valid, one should expect the contrary, namely a negative impact of exchange rate flexibility on the degree of reforms, net of other factors. 
(3) If third factors like the initial need for reforms, the so-called problem pressure, dominate the relationship, the exchange rate regime should turn out to be insignificant.

Note that (1) to (3) should be valid not only for labor market reforms but also for complementary structural reforms in the goods and the financial markets.

\subsection{Data and Definitions}

We estimate and test the conjectured impact of the exchange rate regime on the degree of market-oriented reforms based on a panel of 178 countries and a panel of 23 OECD economies. ${ }^{16}$ Our samples cover the period 1970 to 2000 in order to exploit all available data information. However, in view of the problems with the last years of the Bretton Woods system which are characterized by still significant capital controls and quite autonomous monetary policies, we also consider estimates that exclude the observations before 1980. In line with our theoretical model, our empirical analysis focuses on the impact of the exchange rate regime on the degree of market-oriented reforms.

As dependent variable we use the extent of economic liberalization as measured by the Economic Freedom of the World (EFW) index and the sub-indices money and banking system, government size and labor market, credit and business regulation, respectively (Gwartney and Lawson 2003, Gwartney et al. 2003). These indices range from one to ten, with a high value corresponding to a high level of economic freedom. A positive change of the index therefore indicates market-oriented reforms. The EFW index and the sub-indices are available in five-year intervals over the period $1970-2000 .{ }^{17}$ Hence, we focus on a wider policy reform data base than Duval and Elmeskov (2005), who 
investigate data from five key policy areas: unemployment benefit systems, labor taxes, employment protection legislation, product market regulation and retirement schemes.

Among the explaining variables, our discussion focuses on the measure of exchange rate flexibility. In section 3.2, we argued that we prefer to measure the loss of autonomy of monetary policy by the degree of participation in any kind of fixed exchange rate agreement. This approach allows to exploit a wider cross-country / time-series dataset of structural reforms than would otherwise be possible. As a result, we feel justified to apply an econometric analysis of reform determinants which includes the degree of exchange rate flexibility as one of the explanatory variables. However, one obvious drawback of our analysis is that it does not cover some of the idiosyncratic characteristics of currency unions compared with other fixed exchange-rate arrangements. In particular, the EMU example reveals that the adoption of a single currency makes the TINA argument emphasized in section 2.1 more compelling than in the case of other, less irreversible exchange-rate regimes. With an eye on these arguments, we decided to employ the Reinhart und Rogoff (2002) index of de facto exchange rate arrangements. ${ }^{18}$ Reinhart and Rogoff (2002) distinguish between exchange rate pegs (1), limited flexibility (2), managed floating (3), and freely floating (4). ${ }^{19}$ Thus, the higher the index value the higher is the de facto flexibility of exchange rates. For our purpose and due to the time structure of the EFW data, we average the Reinhart and Rogoff (2002) index values over five-year intervals.

The additional control variables that we consider include inflation, economic growth and openness as proxies of the pressure to reform. Data are available from the World Development Indicators database (World Bank, 2002). Economic openness is defined as exports plus imports relative to GDP. To account for the potential endogeneity and in 
accordance with other contributions (e.g., Herz and Vogel, 2005; Lora 2000; Pitlik 2004; Pitlik and Wirth, 2003), we take these variables in first lags. A final set of controls accounts for political and institutional barriers to policy reforms. Here we include POLCON5 and the number of government changes. POLCON5 (Henisz, 2000, 2002) measures the effective political restrictions on executive behavior. It accounts for the veto powers of the executive, two legislative chambers, the sub national entities and an independent judiciary. The index ranges from zero to one, where a higher value indicates stronger political constraints on the government. Given the time structure of our dependent variable, we take average values of POLCON5 for the respective five-year interval. GOVCHANGES counts the number of government changes that entail a significant programmatic reorientation. The data are taken from Beck et al. (2001). The credibility and reliability of economic policy is assumed to decrease with the number of government changes. Frequent changes shorten the administration's time horizon and lead to a stronger discounting of positive future payoffs from reforms.

\subsection{Empirical model and results}

\subsubsection{Empirical model}

To investigate the impact of economic crises and political and institutional characteristics on reforms, we estimate the equation:

$$
\Delta E F W_{i t}=\alpha_{0}+\alpha_{1} E F W_{i, t-1}+\alpha_{2} E X R_{i t}+\alpha_{3}{ }^{\prime} X_{i, t-1}+\alpha_{4}{ }^{\prime} Y_{i t}+\eta_{i}+\lambda_{t}+\varepsilon_{i t},
$$

where $\triangle \mathrm{EFW}$ represents our index of reforms, i.e. the change in economic freedom. EXR is our measure for exchange rate flexibility, $\mathrm{X}$ is the vector of macroeconomic variables (growth, inflation, openness), Y captures the political and institutional determinants of the capacity to reform, and $i$ is a country index Most importantly, we expect $\alpha_{2}<0$ to hold, since a high degree of exchange rate flexibility should lead to more re- 
forms (see sections 3.1 and 3.2). However, if the TINA-view is valid, one should expect the contrary, namely $\alpha_{2}>0$. To account for unobserved heterogeneity across countries and across time, we add individual-specific $\left(\eta_{i}\right)$ and time-specific effects $\left(\lambda_{t}\right)$. The latter should help to capture the systematic impact of omitted variables. The short time dimension of our sample complicates the use of country fixed effects, however. There are at most six observations per country. Consequently, any estimate of the individual effects would be very imprecise, while significantly reducing the degrees of freedom.

To avoid these problems, a common approach is to estimate a within-group transformation (e.g., Pitlik, 2004; Pitlik and Wirth, 2003). The within transformation considers differences from the respective country average. As a result, country dummies and timeinvariant indicators drop out (Baltagi, 1995; Hsiao, 2003). The flip side is that the within transformation neglects the cross-sectional information in the data. It does not allow to estimate the impact of time-invariant cross-sectional differences on economic reform. To include the cross-sectional differences, which should account for most of the variation in our sample, we also run a pooled OLS regression without individualspecific effects. The latter exploits both the cross-sectional information and the time dimension in our sample. The downside here is that pooled OLS estimates without country effects can be subject to the omitted variable bias.

\subsubsection{Results}

This section presents the regression results for our broad country sample and for the sample of high-income OECD economies, respectively. We report the regression results for overall liberalization, money and banking system, government size and market regulation as dependent variables. Tables 2 to 7 display the panel estimates from the OLS 
within transformation, which neglects the variance across countries, and from pooled OLS, which exploits the time and the country dimension of our sample without including individual fixed effects.

\section{- Tables 2 and 3 about here -}

A robust result in all regressions is the negative impact of the initial level of economic freedom on the extent of subsequent market-oriented reforms. The higher the initial level of economic freedom, the lower are the scope and the need for further liberalization and the higher is conditional policy convergence (Duval and Elmeskov, 2005: 23 ff.). The main interest of our paper lies on the impact of the exchange rate system on market-oriented reforms, however. Here, we find a robust negative impact of higher exchange rate flexibility on overall liberalization, as measured by the chain-linked EFW index, in our world-wide sample. This result does not carry over to the sub-sample of OECD economies, however. In the latter case, we obtain insignificant or even positive coefficients. Neither is the positive impact of fixed exchange rates on the degree of liberalization replicated for the sub-indices government size and market regulation. For both measures we obtain either insignificant or positive coefficients.

\section{- Tables 4 and 5 about here -}

How can we reconcile the different findings for the overall index, on the one hand, and the sub-indices, on the other hand? A candidate explanation is that the positive impact of fixed exchange rates on market-oriented reforms is entirely driven by its positive impact on price stability and the credibility of monetary policy. The significantly negative impact of exchange rate flexibility on the monetary and banking reform index in most of the regressions in the world sample supports this hypothesis and our prior from section 2.1 (see Tables 4 and 5). As a further element, the fact that our sub-indices are 
not chain-linked reduces the reliability of the respective data, and it may distort the results.

\section{- Tables 6 to 9 about here -}

Taken together, the insignificant or even positive parameter estimates for the impact of exchange rate flexibility on government sector reform and on market deregulation contradict the hypothesis that the exchange rate commitment has a positive impact on structural reforms. Concerning the other explanatory variables, we find a significant negative impact of the initial levels of economic freedom on subsequent reforms. Furthermore, we find a robust positive impact of political constraints on liberalization and, in the worldwide sample, a negative impact of frequent government changes. A more detailed discussion of similar results in a different model context is given in Herz and Vogel (2005) and Pitlik (2004).

\subsubsection{Robustness Checks}

The results in Tables 2 to 9 are retrieved from OLS-within and pooled OLS estimations. For each of the four different reform indices, we present both the world sample and OECD sample based estimates. One problem of both within and pooled OLS is that it does not account for the dynamic structure of our regression equation and for the possible endogeneity of contemporary explanatory variables. The inclusion of a lagged dependent variable and the possible endogeneity of other explanatory variables violate the assumption of strict exogeneity in static panel regressions (see Baltagi, 1995; Hsiao, 2003 for a detailed discussion). The endogeneity of explanatory variables potentially applies to both the economic indicators and the political and institutional characteristics. The possibility of reverse causation is most obvious for the macroeconomic indicators, which is the reason why we use them as lagged values in our analysis. Economic crises 
may affect economic policy, but economic policy also impacts on economic performance. Reverse causation may also apply to variables like the stability of government and the number of effective veto players, however.

We therefore rerun the regression with the instrumental variable General Method of Moments estimator (IV-GMM) by Arellano and Bond (1991). IV-GMM deals with individual fixed effects and endogeneity. It estimates the regression equation in first differences and uses lagged values of the regressors as instruments (Baltagi, 1995; Hsiao, 2003). The drawback, as with OLS-within, is that the differencing disregards the crosssectional information in our data. Secondly, the time dimension of our data set is short and the availability of lagged variable values as instruments therefore very limited. As a robustness check we applied the IV-GMM estimator to our worldwide sample. We focus on the one-step GMM estimates. The results are similar to the OLS estimates. They replicate the negative impact of exchange rate flexibility on overall liberalization and the insignificant parameter estimates for the sub fields of government size and market regulation. The only difference is that the impact of the exchange rate regime on money and banking sector reform appears insignificant in the GMM estimation. ${ }^{20}$

Our empirical analysis supposes that the exchange rate regime reflects the degree of monetary commitment or autonomy (discretion). Flexible exchange rates indicate autonomy and a discretionary monetary policy, whereas a fixing indicates the adoption of a monetary rule. Monetary commitment, in turn, does not necessarily imply a fixed exchange rate, however. Hence, we check the robustness of our results using an alternative indicator of monetary policy commitment in order to make sure that our definition of monetary autonomy does not create a bias in the estimations - probably in the direction of not finding any effects (Freytag, 2005). The indicator is available for a smaller 
set of countries only, which basically coincides with the 23 high-income OECD economies. The data are only available at the frequency of decades. Therefore, including the monetary commitment indicator reduces our data set to the OECD sub-sample with at maximum three observations per country.

\section{- Tables 10 and 11 about here -}

The results of this exercise are displayed in Tables 10 and 11 . We find the commitment indicator to be insignificant in explaining overall liberalization. The result is compatible with the insignificance of the exchange rate regime in the OECD sample regression. For the money and banking sector we obtain an insignificant (pooled OLS) or a positively significant (within) coefficient on commitment, which is compatible with the results in Table 5 above. The commitment proxy is insignificant in the case of government sector reform, thus broadly reproducing the results in Table 7 . Finally, monetary commitment appears to have a positive impact on market liberalization in the within regression, but not for pooled OLS. This contrasts the picture in Table 9, where exchange rate flexibility is either insignificant or appears to promote liberalization.

Finally, we check a few properties of the model derived in section 3.2 empirically and use this as a robustness check. One precondition for more reforms under a discretionary regime derived in section 3.2 was a generally low level of inflation. The lower the level of inflation is, the stronger are the incentives to inflate since the marginal gains of inflation, in the form of a lower natural rate of unemployment, rise with decreasing inflation (Akerlof, Dickens and Perry, 1996, and Calmfors, 1997: 24). From this perspective, lower initial inflation should lead to a higher degree of reforms under policy autonomy, i.e. flexible exchange rates. 
In order to test this hypothesis empirically, we used $30 \%$ inflation as a threshold and applied both an interaction term, ,inflation dummy times exchange rate regime“. Since the number of high inflation periods is small within the OECD, we only consider the world sample in this case. This leads to the following results. Including the interaction term ,inflation dummy times exchange rate regime“ even increases the negative impact of flexibility on reforms based on the index of overall liberalization. This result clearly contradicts the hypothesis of low inflation as a catalyst of more reforms. Analogously, the impact of exchange rate flexibility on reforms of the government sector is higher (significant positive instead of insignificance) with high inflation. In contrast, the different notions of high and low inflation do not play any role for the degree of market regulation. In both cases, the exchange rate regime and the inflation variable are insignificant. If we apply the monetary and banking reform index, the interaction term ,inflation dummy times exchange rate regime" turns out to be insignificant. Hence, also in this case low inflation does not lead to a higher degree of reforms if there is policy autonomy in the form of flexible exchange rates. ${ }^{21}$

The main results of our analysis about the impact of exchange rate commitment on economic reform can be summarized as follows. For our broad country sample, the adoption of an exchange rate rule is positively correlated with market-oriented reforms in general, and with reforms in the money and banking sector in particular. For the government sector and for market regulation, we do not find a robust significant effect, however. We can thus assume that it is the positive impact of exchange rate commitment on the money and banking sector that accounts for the positive impact on marketoriented reforms in general. In the case of the OECD sample we do not find evidence for a significant impact of a rule-based or discretionary exchange rate policy on eco- 
nomic reforms . The use of an alternative indicator of monetary policy commitment supports these findings.

\section{Conclusions}

In this paper we estimated and tested the relationship between exchange rate regimes and the degree of economic reforms by estimating panel regressions. As dependent variable we used the degree of market-oriented reforms. As independent variables we included indicators of the flexibility of the exchange rate system, the stability of monetary policy and further control variables like economic performance as a proxy of reform pressure and institutional impediments to further reform. The results of our empirical analysis suggest that the adoption of an exchange rate rule is positively correlated with market-oriented reforms in a broad world sample, and with reforms in the money and banking sector in particular. For the government sector and for market regulation, we do not find a robust significant effect, however. The impact of exchange rate policy on economic reforms is not significant in the sample of OECD countries. The use of an alternative indicator of monetary policy commitment supports these findings.

Seen on the whole, these results do not confirm the implications of our Calmfors-type model, namely that one should observe a higher (overshooting) degree of reforms under monetary policy autonomy. Instead, one should stress another important implication of our theoretical model: autonomous discretionary policy achieves a lower total welfare than rule-based monetary policy. This is valid in spite of the higher partial incentive to implement labor market reforms contained in the model. Insofar as a superior instrument is available for the parallel reduction of the equilibrium inflation rate, namely a significant reduction of monetary policy autonomy, the higher degree of labor-market 
reforms under discretionary monetary policy which we found empirical evidence for only signals a form of overshooting. Such kinds of reform are not beneficial anyway and cannot be corroborated empirically in our investigation.

However, our empirical results at least partly confirm the TINA argument that limiting monetary policy autonomy (like a common monetary policy under EMU from the perspective of a single EMU-in country) tends to raise the probability of the implementation of structural reforms / liberalisation steps. The elimination of the exchange rate option seems to extend the incentives for painful but long-term beneficial institutional adjustments on labor and product markets for developing countries and emerging markets. This might represent an important message for those who have to decide about the entry into a currency union or a hard currency peg.

Finally, the exchange rate regime often turned out to be insignificant when we applied it to reforms in areas other than the money and banking system. Instead, the usual suspects like problem pressure as measured by the initial degree of freedom dominate the regressions. In a sense, one could even argue that a change in a nominal variable like for instance the exchange rate regime, appears to have mainly effects on other nominal variables like the monetary and banking system, a view often condemned as too pessimistic in the discussions during the run-up to the Euro. From this perspective, our results are strikingly similar to the huge amount of non-results which Duval and Elmeskov (2005) found for their sample of EMU countries. Hence, the upshot of our study is that one should not exaggerate the impact of monetary policy autonomy and the exchange rate regime on economic freedom in view of a large status-quo bias and pathdependence of reform intensity. There is no empirical base for the argument that discre- 
tionary monetary policy is favorable because it gives more incentives for structural reforms. This insight probably represents the most robust result of this contribution.

\section{Endnotes}

1 OECD (2005) applies a consistent procedure to derive policy priorities to foster growth across OECD countries and identifies labor market reforms as being particularly important in, e.g., the Euro area. However, this does not at all imply that reforms in other areas are unimportant. Hence, we analyze a variety of different reform measures in the empirical part of the paper.

2 Van Poeck and Borghijs (2001) argue that the prospect of qualifying for EMU should provide as big an incentive for labor-market reform as EMU membership itself. They conclude that EMU countries did not reform more than other countries and, unlike elsewhere, their progress on reform seemed unrelated to the initial level of unemployment. For a period from the early nineties up to 1999 , Bertola and Boeri (2001), they only focus cash transfers to people of working age, e.g. unemployment benefits, and on job protection. They arrive at exactly opposite conclusions, i.e. reforms accelerated more in the euro area than outside.

The IMF (2004) looks at the impact of a range of factors including macroeconomic conditions, political institutions, reform design and variables aimed to capture attitudes towards structural reform on different policy areas across OECD countries from the mid-1970s up to the late 1990s. It finds that EU membership leads to faster moves towards liberalization of product markets. However, it does not clarify whether this represents an effect of EMU and/or policies to prepare for EMU. See also Duval and Elmeskov (2005), p. 10.

3 For a recent survey of the arguments see Duval and Elmeskov (2005) and Hochreiter and Tavlas (2005).

4 See Alogoskoufis (1994), Calmfors (1997), Duval and Elmeskov (2005: 6), Mélitz (1997) and Sibert and Sutherland (1997). 
5 See, Bean (1998), Calmfors (1998: 28); Duval and Elmeskov (2005: 5) and Saint-Paul and Bentolila (2000).

6 The analytical framework was initially developed by Barro and Gordon (1983, 1983a), Kydland and Prescott (1977), Sibert and Sutherland (1997), and Svensson (1997).

7 Alternatively, labor market reforms might contain the reduction of unemployment benefits, the rise of the efficiency of labor market policy, the substitution of collective by individual wage negotiations, lower minimum wages for young employees, the revision of the laws of wage negotiations (increasing the negotiation power of employees) and the reduction of both taxes and employment protection.

8 McCallum (1995) and Jensen (1997) both refer to the problem that the combination of "delegation and proper incentive schemes" is not able to eliminate the inflation bias completely as long as a discretionary national stabilization policy is maintained.

9 Concerning the structure of the game, the expected loss function should be minimized. But for clarity of exposition, the expectations operator is left out.

10 Strictly speaking, the monetary rule can in this case simply be expressed as a k-percent rule without feedback component.

11 An increase of nominal rigidities intensifies the credibility problem of monetary policy. Hence, the incentive of politicians to reduce the increasing credibility problem by more labor market reforms expands. However, this effect should be - and actually is according to our estimates in section 4.3 - less relevant in praxi if the nominal rigidities are diminished by market-oriented reforms, resulting in higher wage flexibility.

12 Early sources are Alesina (1992: 13-14), Alesina and Roubini (1992: 680) and Annett (1993: 25 and 42).

13 See Alogoskoufis, Lockwood and Philippopoulos (1992: 1384) and Ellis and Thoma (1990: 17 and 24). 
$\overline{14}$ See Alesina and Roubini (1992: 673-674), Alogoskoufis and Philippopoulos (1992: 397), Alogoskoufis, Lockwood and Philippopoulos (1992: 1370-1371) and Annett (1993: 25 and $33)$.

15 See Simmons (1994: 59), Ellis and Thoma (1990) estimate rational partisan theory approaches for open economies. In their study, party-specific inflation rates lead to party specific differences in exchange rate movements.

16 The 23 OECD economies correspond to the category high-income industrialized countries in the World Development Indicators database (World Bank, 2002) and cover Australia, Canada, the former EU-15, Iceland, Japan, New Zealand, Norway, Switzerland and the United States.

17 We use the chain-weighted EFW index (Gwartney et al., 2003), which corrects for the limited availability of some components over time. This chain-linked index is only available for the summary indicator, however. For the sub areas government size and market regulation we have to rely on uncorrected data.

18 The de facto measure improves on the de jure classification of IMF (2003) since it takes into account that de jure exchange rate regimes are not necessarily applied in practice. This has especially been the case in developing countries but also in industrialized countries. Austria, e.g., had a de facto fixed exchange rate regime vis-à-vis Germany for a long time without being a formal member of the exchange rate mechanism of the EMS. See Hochreiter and Tavlas (2005).

19 Reinhart and Rogoff (2002) include freely falling rates as an additional category. We add the cases of freely falling rates to the free-float category, however.

20 The results are available on request.

21 The results are available on request. 


\section{References}

Akerlof, G., Dickens, W. and Perry, G. (1996). The Macroeconomics of Low Inflation. Brookings Papers on Economic Activity, 1-59.

Alesina, A. (1992). Political Models of Macroeconomic Policy and Fiscal Reform. Policy Research Working Papers, The World Bank, WPS 970.

Alesina, A. and Rosenthal, H. (1989). Partisan Cycles in Congressional Elections and the Macroeconomy. American Political Science Review 83: 373-398.

Alesina, A. and Roubini, N. (1992). Political Cycles in OECD Economies. Review of Economic Studies 59: 663-688.

Alogoskoufis, G.S. (1994). On Inflation, Unemployment and the Optimal Exchange Rate Regime. In F. van der Ploeg (Ed.), The Handbook of International Macroeconomics, 192-223. Cambridge, Oxford: Blackwell.

Alogoskoufis, G.S. and Philippopoulos, A. (1992). Inflationary Expectations, Electoral Uncertainty and the Exchange Rate Regime - Greece 1958-1989. European Journal of Political Economy 8(3): 375-399.

Alogoskoufis, G.S., Lockwood, B., and Philippopoulos, A. (1992). Wage Inflation, Electoral Uncertainty and the Exchange Rate Regime - Theory and UK Evidence. Economic Journal 102: 1370-1394.

Annett, A.M. (1993). Elections and Macroeconomic Outcomes in Ireland - 1948-1991. The Economic and Social Review 25: 21-47. 
Arellano, M. and Bond, S. (1991). Some tests of specification for panel data: Monte Carlo evidence and an application to employment equations. Review of Economic Studies 58: 277-297.

Baltagi, B. (1995). Econometric Analysis of Panel Data, Chichester: John Wiley and sons.

Barro, R.J. and Gordon, D.B. (1983). Rules, Discretion and Reputation in a Model of Monetary Policy. Journal of Monetary Economics 12(1): 101-121.

Barro, R.J. and Gordon, D.B (1983a). A Positive Theory of Monetary Policy in a Natural Rate Model. Journal of Political Economy 91: 589-610.

Bean, C. (1998). The Interaction of Aggregate-demand Policies and Labor-market Reform. Swedish Economic Policy Review5(2).

Beck, T., Clarke, G., Groff, A., Keefer, P. and Walsh, P. (2001). New Tools in Comparative Political Economy: The Database of Political Institutions. World Bank Economic Review 15(1): 165-176.

Beetsma, R. and Bovenberg, L. (1998). The Optimality of a Monetary Union without a Fiscal Union. CEPR Discussion Paper 1975, September. London.

Belke, A. and Gros, D. (1999). Estimating the Costs and Benefits of EMU: The Impact of External Shocks on Labor Markets. Weltwirtschaftliches Archiv 135: 1-48.

Belke, A. and Kamp, A. (1999). When Do Labor Market Reforms Achieve a Double Dividend under EMU? Discretionary versus Rule Based Monetary Policy Revisited. Journal of Economic Integration 14(4): 572-605.

Berthold, N. and Fehn, R. (1996). The Positive Economics of Unemployment and Labor Market Inflexibility. Kyklos 49: 583-613. 
Bertola, G. and T. Boeri (2001). EMU Labor Markets Two Years On: Microeconomic Tensions and Institutional Evolution. Paper presented at the Workshop "The Functioning of EMU: Challenges of the Early Years" organized by the Directorate General for Economic and Financial Affairs, European Commission, Brussels, 21-22 March 2001, April 27th 2001 version.

Blanchard, O., Dornbusch, R., Dreze, J., Giersch, H., Layard, R. and Monti, M. (1986). Employment and Growth in Europe - A Two-Handed Approach. In O. Blanchard, R. Dornbusch and R. Layard (Eds.), Restoring Europe's Prosperity, 95-124. Cambridge, Mass.: MIT Press.

Calmfors, L. (1997). Unemployment, Labor-Market Reform and EMU. IIES Seminar Paper 639. Institute for International Economic Studies, Stockholm.

Calmfors, L. (1998). Macroeconomic Policy, Wage Setting and Employment - What Difference Does the EMU Make?. Oxford Economic Policy Review 14: 125-151.

Calmfors, L. (2001). Unemployment, Labor-Market Reform and Monetary Union. Journal of Labor Economics 19(2): 265-289.

Castrén, O., Takalo, T. and Wood, G. (2004). Labor Market Reform and the Sustainability of Exchange Rate Pegs. ECB Working Paper Series No. 406, November. European Central Bank, Frankfurt.

Dornbusch, R. and Favero, C.A. (1998). A Red Letter Day?. CEPR Discussion Paper 1804, February. London.

Duval, R. and Elmeskov, J. (2005). The Effects of EMU on Structural Reforms in Labor and Product Markets. Mimeo. Paper prepared for the Conference on "What Effects is 
EMU Having on the Euro Area and its Member Countries?" organised by the European Central Bank in Frankfurt. June.

Ellis, C.J. and Thoma, M.A. (1990). The Implications for an Open Economy of Partisan Political Business Cycles: Theory and Evidence. University of Oregon. Department of Economics Working Paper 90/2.

Freytag, A. (2005). The Credibility of Monetary Reform: New Evidence. Public Choice 121, forthcoming.

Grüner, H.S. and Hefeker, C. (1996). Militant Labor and Inflation Aversion - The Impact of EMU on Labor Union Interaction. University Bonn, SFB 303 Discussion Paper A-539.

Gwartney, J. and Lawson, R. (2003). The Concept and Measurement of Economic Freedom. European Journal of Political Economy 19(3): 405-430.

Gwartney, J., Lawson, R., Park, W. and Skipton, C. (2003). Economic Freedom of the World: 2003 Annual Report. Fraser Institute, Vancouver.

Haffner, R.C.G., Nickell, S., Nicoletti, G., Scarpetta, S., Zoega, G. (2000). European Integration, Liberalisation and Labor Market Performance: Report for the Fondazione Rodolfo DeBenedetti.

Henisz, W. (2000). The Institutional Environment for Economic Growth. Economics and Politics 12(1): 1-31.

Henisz, W. (2002). The Institutional Environment for Infrastructure Investment. Industrial and Corporate Change 11(2): 355-389.

Herz, B. and Vogel, L. (2005). Determinants of Market-Oriented Policy Reforms: An Empirical Analysis. Mimeo. 
Hochreiter, E. and Tavlas, G.S. (2005). The Two Roads to the Euro: The Monetary Experiences of Austria and Greece. In S. Schadler (Ed.), Euro Adoption in Central and Eastern Europe - Opportunities and Challenges. Washington/DC: International Monetary Fund.

Hsiao, C. (2003). Analysis of Panel Data. Cambridge: Cambridge University Press.

IMF (2003). International Financial Statistics. CD-ROM. International Monetary Fund, Washington DC.

IMF (2004). Fostering Structural Reforms in Industrial Countries. Chapter III in World Economic Outlook. Advancing Structural Reforms, International Monetary Fund, Washington D.C.

Jensen, H. (1997). Credibility of Optimal Monetary Delegation. American Economic Review 87: 911 - 920.

Johansson, A. (1998). The Interaction between Labor Market Policy and Monetary Policy: An Analysis of Time Inconsistency. Mimeo. Paper presented at the Institute for International Economic Studies Seminar in Stockholm. April.

Jimeno, J. (2005), Comments on Duval, R., Elmeskov, J. “The Effects of EMU on Structural Reforms in Labor and Product Markets," Paper prepared for the Conference on "What Effects is EMU Having on the Euro Area and its Member Countries?" organised by the European Central Bank in Frankfurt. June.

Jonsson, G. (1997). Monetary Politics and Unemployment Persistence. Journal of Monetary Economics 39(2): 303-325.

Katzenstein, P. (1985). Small States in World Markets. Ithaca: Cornell University Press. 
Krugman, P. and Obstfeld, M. (2003). International Economics - Theory and Policy, Boston, Mass.: Addison Wesley.

Kydland, F.E. and Prescott, E.C. (1977). Rules Rather than Discretion: The Inconsistency of Optimal Plans. Journal of Political Economy 85: 473-491.

Layard, R., Jackman, R. and Nickell, S. (1991). Unemployment. Oxford: Oxford University Press.

Layard, R, Jackman, R. and Nickell, S. (1994). The Unemployment Crisis. Oxford: Oxford University Press.

Lindbeck, A. (1992). Macroeconomic Theory and the Labor Market. European Economic Review 36(2-3): 209-235.

Lohmann, S. (1992). The 'Optimal Degree of Commitment: Credibility and Flexibility. American Economic Review 82: 273-286.

Lohmann, S. (1993). Electoral Cycles and International Policy Coordination. European Economic Review 37(7): 1373-1391.

Lora, E. (2000). What Makes Reforms Likely? Timing and Sequencing of Structural Reforms in Latin America. Inter-American Development Bank Working Paper 424. Washington.

McCallum, B.T. (1995). Two Fallacies Concerning Central-Bank Independence. American Economic Review (Papers and Proceedings) 85: 207-211.

Mélitz, J. (1997). The Evidence about the Costs and Benefits of EMU. Swedish Economic Policy Review 4(2): 191-234. 
Nicoletti G., Golub, S., Hajkova, D., Mirza, D. and Yoo, K.-Y. (2003). Policies and International Integration: Influences on Trade and Foreign Direct Investment. OECD Economics Department Working Papers 359.

Nickell, S. (1997). Unemployment and European Labor Market Rigidities - Europe versus North America. Journal of Economic Perspectives 11: 55-74.

Nickell, S. (2005). Comments on Duval, R., Elmeskov, J. "The Effects of EMU on Structural Reforms in Labor and Product Markets,". Mimeo. Paper prepared for the Conference on "What Effects is EMU Having on the Euro Area and its Member Countries?” organised by the European Central Bank in Frankfurt. June.

OECD (2005). Economic Policy Reforms. Going for Growth. Paris: OECD.

Ozkan, F.G., Sibert, A.C. and Sutherland, A. (1997). Monetary Union, Entry Conditions and Economic Reform. CEPR Discussion Paper 1720, November. London.

Persson, T. and Tabellini, G. (1993). Designing Institutions for Monetary Stability. Carnegie-Rochester Conference Series on Public Policy 39: 53-84.

Pitlik, H. and Wirth, S. (2003). Do crises promote the extent of economic liberalization?. European Journal of Political Economy 19(3): 565-581.

Pitlik, H. (2004). Are Less Constrained Governments Really More Successful in Executing Market-Oriented Policy Changes?. Diskussionsbeiträge aus dem Institut für Volkswirtschaftslehre der Universität Hohenheim 255/2005. University Hohenheim, Stuttgart.

Reinhart, C.M. and Rogoff, K.S. (2002). The Modern History of Exchange Rate Regime Arrangements: A Reinterpretation. NBER Working Paper 8963, National Bureau of Economic Research. Cambridge, Mass. 
Rodrik, D. (1996). Understanding Economic Policy Reform. Journal of Economic Literature 34(1): 9-41.

Saint-Paul, G. (1993). On the Political Economy of Labor Market Flexibility. NBER Macroeconomics Annual: 151-187.

Saint-Paul, G. (1996). Exploring the Political Economy of Labor Market Institutions. Economic Policy 23: 265-315.

Saint-Paul, G., Bentolila, S. (2000). Will EMU Increase Eurosclerosis?, International Macroeconomics and Labor Economics, CEPR Discussion Paper 2423, April, London.

Sibert, A.C. and Sutherland, A. (1997). Monetary Regimes and Labor Market Reform. CEPR Discussion Paper 1731, November. London.

Simmons, B.A. (1994). Who Adjusts? - Domestic Sources of Foreign Economic Policy During the Interwar Years. Princeton: Princeton University Press.

Svensson, L. (1997). Optimal Inflation Targets, "Conservative" Central Banks, and Linear Inflation Contracts. American Economic Review 87: 98-114.

van Poeck, A., Borghijs, A. (2001). EMU and Labor Market Reform: Needs, Incentives and Realisations. Oxford: Blackwell Publishers.

Walsh, C. (1995). Optimal Contracts for Independent Central Bankers. American Economic Review 85: 150-167.

World Bank (2002). World Development Indicators. Washington, DC: World Bank Publications. 


\section{Data and Variables}

\begin{tabular}{|l|l|}
\hline \multicolumn{1}{|c|}{ Variable } & \multicolumn{1}{|c|}{ Source } \\
\hline $\begin{array}{l}\text { Economic freedom } \\
\text { - Summary indicator } \\
\text { - Money and banking system } \\
\text { - Government size } \\
\text { - Regulation }\end{array}$ & Gwartney et al. (2003) \\
\hline $\begin{array}{l}\text { Exchange rate regime } \\
\text { Monetary commitment }\end{array}$ & Reinhart and Rogoff (2002) \\
\hline Inflation & Freytag (2005) \\
\hline Economic growth & OECD (2002), World Bank (2002) \\
\hline Economic openness (trade/ GDP) & OECD (2002), World Bank (2002) \\
\hline Political constraints (POLCON5) & OECD (2002), World Bank (2002) \\
\hline $\begin{array}{l}\text { Number of government changes } \\
\text { GOVCHANGES) }\end{array}$ & Benisz (2000, 2002) \\
\hline
\end{tabular}




\section{Tables}

Table 1. Economic openness and exchange rate regimes 1970-2000

\begin{tabular}{|l|c|c|c|}
\hline Degree of openness (Trade/ GDP) & Average & Median & Observations \\
\hline$<0.25$ & 2.65 & 2.93 & 60 \\
\hline $0.25-0.75$ & 2.27 & 2 & 471 \\
\hline $0.75-1.25$ & 1.98 & 2 & 200 \\
\hline$>1.25$ & 1.51 & 1 & 59 \\
\hline
\end{tabular}

Sources: The data on exchange rate flexibility are taken from Reinhart and Rogoff (2002). We measure economic openness as the sum of exports plus imports relative to GDP). The data are extracted from the World Development Indicators database (World Bank 2002). 
Table 2. World sample panel estimates for overall liberalization (t-values in parentheses, significance levels: $10 \% *, 5 \% * *, 1 \% * * *$ )

\begin{tabular}{|c|c|c|c|c|c|c|c|c|}
\hline \multirow[b]{3}{*}{ EXR flexibility } & \multicolumn{4}{|c|}{ EFW period 1970-2000 } & \multicolumn{4}{|c|}{ EFW period $1980-2000$} \\
\hline & \multicolumn{2}{|c|}{ OLS within } & \multicolumn{2}{|c|}{ OLS pooled } & \multicolumn{2}{|c|}{ OLS within } & \multicolumn{2}{|c|}{ OLS pooled } \\
\hline & $\begin{array}{c}-\mathbf{0 . 1 8} * * * \\
(-3.86)\end{array}$ & $\begin{array}{c}-\mathbf{0 . 1 5} * * * \\
(-3.06)\end{array}$ & $\begin{array}{c}-\mathbf{0 . 0 9} * * * \\
(-3.16)\end{array}$ & $\begin{array}{c}-\mathbf{0 . 0 9} * * * \\
(-3.60)\end{array}$ & $\begin{array}{c}-\mathbf{- 0 . 2 0} * * * * \\
(-2.72)\end{array}$ & $\begin{array}{c}-\mathbf{- 0 . 0 8 * * * *} \\
(-2.65)\end{array}$ & $\begin{array}{c}-\mathbf{0 . 0 7} * * \\
(-2.21)\end{array}$ & $\begin{array}{c}-\mathbf{- 0 . 0 8}^{* * * *} \\
(-2.65)\end{array}$ \\
\hline EFW (t-1) & $\begin{array}{c}-\mathbf{- 0 . 5 9} * * * \\
(-12.1)\end{array}$ & $\begin{array}{c}-\mathbf{- 0 . 6 3} * * * \\
(-12.1)\end{array}$ & $\begin{array}{c}-\mathbf{0 . 1 6 * * *} \\
(-7.98)\end{array}$ & $\begin{array}{c}-\mathbf{- 0 . 2 9} * * * \\
(-10.2)\end{array}$ & $\begin{array}{c}-\mathbf{- 0 . 6 2 * * *} \\
(-10.3)\end{array}$ & $\begin{array}{c}-\mathbf{- 0 . 6 4 * * *} \\
(-10.7)\end{array}$ & $\begin{array}{c}-\mathbf{0 . 1 7} * * * \\
(-7.96)\end{array}$ & $\begin{array}{c}-\mathbf{0 . 3 0} * * * * \\
(-10.7)\end{array}$ \\
\hline Inflation (t-1) & & $\begin{array}{c}0.01 \\
(0.50)\end{array}$ & & $\begin{array}{c}0.01 \\
(0.37)\end{array}$ & & $\begin{array}{c}0.01 \\
(0.47)\end{array}$ & & $\begin{array}{c}0.01 \\
(0.25)\end{array}$ \\
\hline Growth $(\mathrm{t}-1)$ & & $\begin{array}{c}1.03 \\
(1.33)\end{array}$ & & $\begin{array}{c}0.18 \\
(0.22)\end{array}$ & & $\begin{array}{c}0.94 \\
(1.21)\end{array}$ & & $\begin{array}{c}0.27 \\
(0.30)\end{array}$ \\
\hline Openness (t-1) & & $\begin{array}{c}0.08 \\
(0.18) \\
\end{array}$ & & $\begin{array}{c}0.07 \\
(0.71) \\
\end{array}$ & & $\begin{array}{c}0.29 \\
(0.64) \\
\end{array}$ & & $\begin{array}{c}0.14 \\
(1.35) \\
\end{array}$ \\
\hline POLCONV & & $\begin{array}{c}\mathbf{0 . 9 5} * * * \\
(4.48)\end{array}$ & & $\begin{array}{c}\mathbf{0 . 9 0} * * * \\
(7.35)\end{array}$ & & $\begin{array}{c}1.13 * * * \\
(4.89)\end{array}$ & & $\begin{array}{c}\mathbf{0 . 8 4} * * * \\
(6.42)\end{array}$ \\
\hline GOVCHANGES & & $\begin{array}{c}-\mathbf{0 . 1 3} * * * \\
(-2.87)\end{array}$ & & $\begin{array}{l}\mathbf{- 0 . 0 7 * *} \\
(-2.23)\end{array}$ & & $\begin{array}{c}-\mathbf{- 0 . 1 3} * * * \\
(-2.59)\end{array}$ & & $\begin{array}{l}-\mathbf{0 . 0 7 *} \\
(-1.84)\end{array}$ \\
\hline Constant & & & $\begin{array}{c}0.64 * * * \\
(3.98)\end{array}$ & $\begin{array}{c}1.56^{* * * *} \\
(8.92)\end{array}$ & & & $\begin{array}{c}1.08^{* * *} \\
(7.39)\end{array}$ & $\begin{array}{c}1.47 * * * \\
(8.01)\end{array}$ \\
\hline Time effects $\left(\mathrm{chi}^{2}\right)$ & $195.1 * * *$ & $71.98 * * *$ & $178.9 * * *$ & $64.78 * * *$ & $111.4 * * *$ & $68.16^{* * *}$ & $73.04 * * *$ & $60.45 * * *$ \\
\hline $\mathrm{R}^{2}$ & 0.47 & 0.45 & 0.33 & 0.33 & 0.40 & 0.47 & 0.24 & 0.33 \\
\hline Observations & 518 & 433 & 521 & 438 & 397 & 370 & 400 & 375 \\
\hline
\end{tabular}


Table 3. OECD sample panel estimates for overall liberalization (t-values in parentheses, significance levels: $10 \% *, 5 \% * *, 1 \% * * *$ )

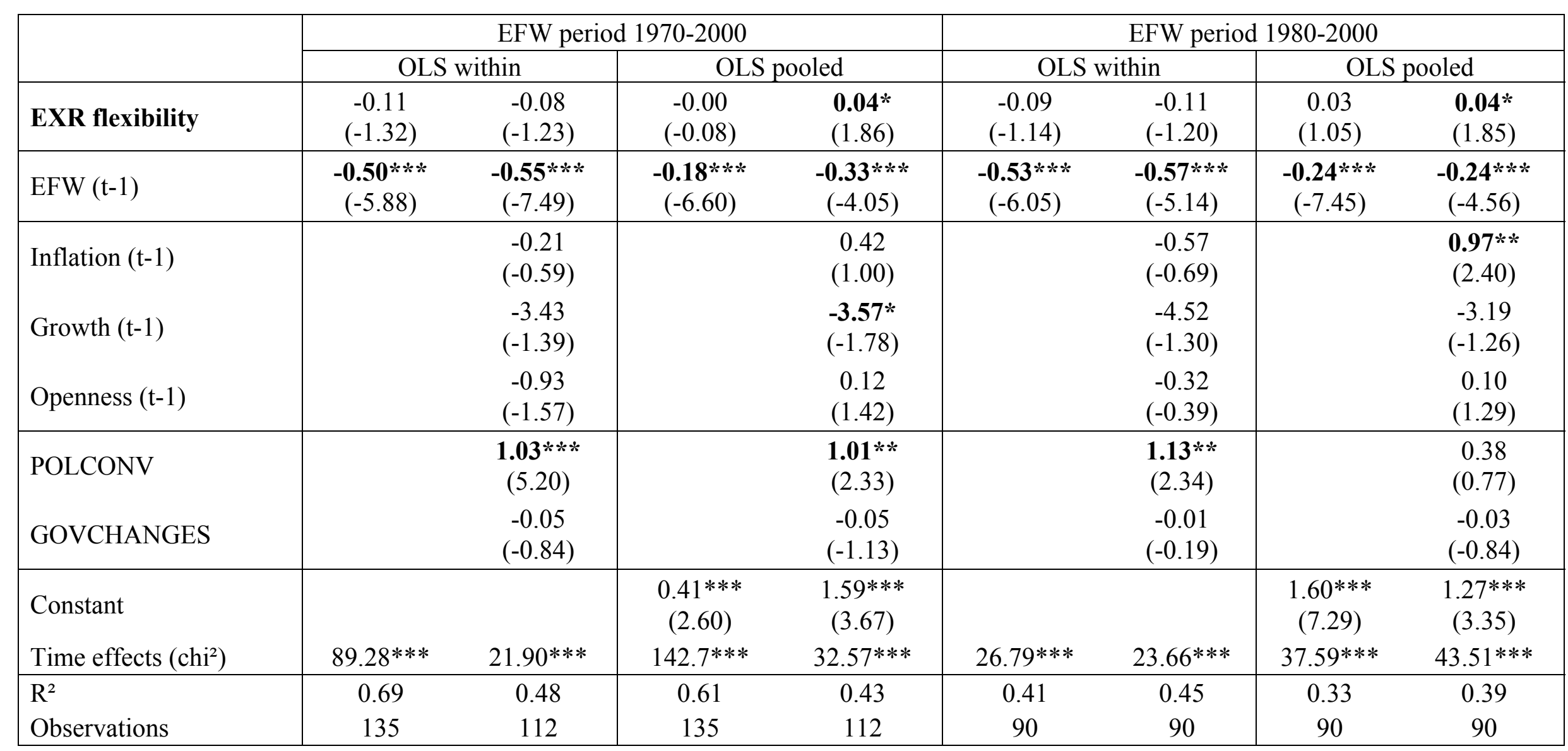


Table 4. World sample panel estimates for money and banking (t-values in parentheses, significance levels: $10 \% *, 5 \% * *, 1 \% * * *)$

\begin{tabular}{|c|c|c|c|c|c|c|c|c|}
\hline \multirow[b]{3}{*}{ EXR flexibility } & \multicolumn{4}{|c|}{ Money and banking period $1970-2000$} & \multicolumn{4}{|c|}{ Money and banking period $1980-2000$} \\
\hline & \multicolumn{2}{|c|}{ OLS within } & \multicolumn{2}{|c|}{ OLS pooled } & \multicolumn{2}{|c|}{ OLS within } & \multicolumn{2}{|c|}{ OLS pooled } \\
\hline & $\begin{array}{c}-\mathbf{0 . 3 2} * * * \\
(-3.20)\end{array}$ & $\begin{array}{c}-\mathbf{0 . 2 8} * * \\
(-2.39)\end{array}$ & $\begin{array}{c}-\mathbf{0 . 2 9} * * * \\
(-3.92)\end{array}$ & $\begin{array}{c}-\mathbf{0 . 3 7} * * * \\
(-5.54)\end{array}$ & $\begin{array}{c}-0.28 \\
(-1.45)\end{array}$ & $\begin{array}{c}-0.11 \\
(-0.67)\end{array}$ & $\begin{array}{c}-\mathbf{0 . 3 1} * * * \\
(-4.03)\end{array}$ & $\begin{array}{c}-\mathbf{0 . 3 5} * * * \\
(-5.22)\end{array}$ \\
\hline$M(t-1)$ & $\begin{array}{c}-\mathbf{- 0 . 6 5 * * *} \\
(-17.7)\end{array}$ & $\begin{array}{c}-\mathbf{0 . 6 1} * * * \\
(-12.4)\end{array}$ & $\begin{array}{c}-\mathbf{- 0 . 2 8 * * *} \\
(-9.26)\end{array}$ & $\begin{array}{c}-\mathbf{- 0 . 3 2} * * * \\
(-9.01)\end{array}$ & $\begin{array}{c}-\mathbf{- 0 . 7 5 * * *} \\
(-11.2)\end{array}$ & $\begin{array}{c}-\mathbf{0 . 6 7 * * *} \\
(-10.9)\end{array}$ & $\begin{array}{c}-\mathbf{0 . 2 9} * * * \\
(-9.57)\end{array}$ & $\begin{array}{c}\mathbf{- 0 . 3 4} * * * \\
(-9.25)\end{array}$ \\
\hline Inflation $(\mathrm{t}-1)$ & & $\begin{array}{c}\mathbf{0 . 1 0} * * * \\
(5.39)\end{array}$ & & $\begin{array}{c}\mathbf{0 . 0 6} * * * \\
(4.06)\end{array}$ & & $\begin{array}{c}\mathbf{0 . 1 0} * * * \\
(5.55)\end{array}$ & & $\begin{array}{c}\mathbf{0 . 0 6} * * * \\
(3.80)\end{array}$ \\
\hline Growth $(\mathrm{t}-1)$ & & $\begin{array}{c}9.01 * * * \\
(4.67)\end{array}$ & & $\begin{array}{c}\mathbf{6 . 8 6} * * * \\
(3.48)\end{array}$ & & $\begin{array}{c}\mathbf{8 . 2 4} * * * \\
(3.77)\end{array}$ & & $\begin{array}{c}\mathbf{8 . 5 3} * * * \\
(4.01)\end{array}$ \\
\hline Openness (t-1) & & $\begin{array}{c}0.79 \\
(0.93) \\
\end{array}$ & & $\begin{array}{c}0.07 \\
(0.34) \\
\end{array}$ & & $\begin{array}{c}1.51 \\
(1.60) \\
\end{array}$ & & $\begin{array}{c}0.13 \\
(0.57) \\
\end{array}$ \\
\hline POLCONV & & $\begin{array}{l}\text { 0.96* } \\
(1.75)\end{array}$ & & $\begin{array}{c}1.36 * * * \\
(6.07)\end{array}$ & & $\begin{array}{l}\text { 1.17* } \\
(1.67)\end{array}$ & & $\begin{array}{c}1.31 * * * \\
(4.85)\end{array}$ \\
\hline GOVCHANGES & & $\begin{array}{c}-\mathbf{0 . 4 1} * * * \\
(-3.46)\end{array}$ & & $\begin{array}{c}-\mathbf{0 . 2 3} * * \\
(-2.41)\end{array}$ & & $\begin{array}{c}-\mathbf{0 . 5 7} * * * \\
(-3.83)\end{array}$ & & $\begin{array}{l}-\mathbf{- 0 . 1 9 *} \\
(-1.71)\end{array}$ \\
\hline Constant & & & $\begin{array}{c}1.44 * * * \\
(4.84)\end{array}$ & $\begin{array}{c}2.33 * * * \\
(7.37)\end{array}$ & & & $\begin{array}{c}2.60 * * * \\
(8.32)\end{array}$ & $\begin{array}{c}2.48^{* * *} \\
(6.72)\end{array}$ \\
\hline Time effects $\left(\mathrm{chi}^{2}\right)$ & $102.1 * * *$ & $44.25 * * *$ & $106.1 * * *$ & $33.20 * * *$ & $49.02 * * *$ & $34.60 * * *$ & $37.42 * * *$ & $26.29 * * *$ \\
\hline $\mathrm{R}^{2}$ & 0.46 & 0.45 & 0.27 & 0.31 & 0.44 & 0.48 & 0.23 & 0.32 \\
\hline Observations & 584 & 460 & 586 & 465 & 401 & 371 & 403 & 376 \\
\hline
\end{tabular}


Table 5. OECD sample panel estimates for money and banking (t-values in parentheses, significance levels: $10 \% *, 5 \% * *, 1 \% * * *)$

\begin{tabular}{|c|c|c|c|c|c|c|c|c|}
\hline \multirow[b]{3}{*}{ EXR flexibility } & \multicolumn{4}{|c|}{ Money and banking period $1970-2000$} & \multicolumn{4}{|c|}{ Money and banking period $1980-2000$} \\
\hline & \multicolumn{2}{|c|}{ OLS within } & \multicolumn{2}{|c|}{ OLS pooled } & \multicolumn{2}{|c|}{ OLS within } & \multicolumn{2}{|c|}{ OLS pooled } \\
\hline & $\begin{array}{c}-\mathbf{0 . 3 3} * * \\
(-2.19)\end{array}$ & $\begin{array}{c}-0.35 \\
(-1.49)\end{array}$ & $\begin{array}{c}-0.07 \\
(-1.12)\end{array}$ & $\begin{array}{c}-0.09 \\
(-1.28)\end{array}$ & $\begin{array}{c}-0.15 \\
(-0.68)\end{array}$ & $\begin{array}{c}-0.28 \\
(-1.09)\end{array}$ & $\begin{array}{c}0.01 \\
(0.14)\end{array}$ & $\begin{array}{c}-0.03 \\
(-0.45)\end{array}$ \\
\hline$M(t-1)$ & $\begin{array}{c}-\mathbf{- 0 . 4 8 * * *} \\
(-6.24)\end{array}$ & $\begin{array}{c}-\mathbf{- 0 . 5 4} * * * \\
(-4.83)\end{array}$ & $\begin{array}{c}-\mathbf{- 0 . 2 5} * * * \\
(-7.05)\end{array}$ & $\begin{array}{c}-\mathbf{- 0 . 3 9} * * * \\
(-4.62)\end{array}$ & $\begin{array}{c}-\mathbf{- 0 . 5 8} * * * \\
(-5.01)\end{array}$ & $\begin{array}{c}-\mathbf{0 . 8 1} * * * \\
(-6.36)\end{array}$ & $\begin{array}{c}-\mathbf{0 . 4 3} * * * \\
(-9.78)\end{array}$ & $\begin{array}{r}-\mathbf{0 . 6 6} * * * * \\
(-6.73)\end{array}$ \\
\hline Inflation $(\mathrm{t}-1)$ & & $\begin{array}{l}-1.39 \\
(-0.80)\end{array}$ & & $\begin{array}{l}-1.60 \\
(-1.08)\end{array}$ & & $\begin{array}{c}-7.75 * * * \\
(-3.30)\end{array}$ & & $\begin{array}{c}-\mathbf{5 . 0 9} * * \\
(-3.01)\end{array}$ \\
\hline Growth $(\mathrm{t}-1)$ & & $\begin{array}{c}-0.03 \\
(-0.00)\end{array}$ & & $\begin{array}{l}-1.08 \\
(-0.14)\end{array}$ & & $\begin{array}{c}-3.50 \\
(-0.30)\end{array}$ & & $\begin{array}{c}-0.13 \\
(-0.02)\end{array}$ \\
\hline Openness (t-1) & & $\begin{array}{l}-2.97 \\
(-1.63)\end{array}$ & & $\begin{array}{c}-0.09 \\
(-0.59)\end{array}$ & & $\begin{array}{c}-0.69 \\
(-0.31)\end{array}$ & & $\begin{array}{c}0.05 \\
(0.25)\end{array}$ \\
\hline POLCONV & & $\begin{array}{l}\text { 1.54\% } \\
(1.94)\end{array}$ & & $\begin{array}{c}1.85 * * * \\
(4.55)\end{array}$ & & $\begin{array}{c}\mathbf{3 . 5 7} * * * \\
(3.88)\end{array}$ & & $\begin{array}{c}2.74 * * * \\
(4.47)\end{array}$ \\
\hline GOVCHANGES & & $\begin{array}{l}-0.10 \\
(-0.50)\end{array}$ & & $\begin{array}{c}-0.01 \\
(-0.10)\end{array}$ & & $\begin{array}{c}-0.04 \\
(-0.16)\end{array}$ & & $\begin{array}{c}0.01 \\
(0.08)\end{array}$ \\
\hline Constant & & & $\begin{array}{c}1.48 * * * \\
(5.20)\end{array}$ & $\begin{array}{c}2.13 * * * \\
(4.55)\end{array}$ & & & $\begin{array}{c}3.44 * * * \\
(7.87)\end{array}$ & $\begin{array}{c}3.65 * * * \\
(5.05)\end{array}$ \\
\hline Time effects $\left(\mathrm{chi}^{2}\right)$ & $62.65 * * *$ & $14.82 * * *$ & $45.71 * * *$ & $14.59 * * *$ & $17.10 * * *$ & $8.725 * *$ & $14.75 * * *$ & $11.13 * *$ \\
\hline $\mathrm{R}^{2}$ & 0.45 & 0.35 & 0.38 & 0.36 & 0.41 & 0.45 & 0.45 & 0.49 \\
\hline Observations & 135 & 112 & 135 & 112 & 90 & 90 & 90 & 90 \\
\hline
\end{tabular}


Table 6. World sample panel estimates for government size (t-values in parentheses, significance levels: $10 \% *, 5 \% * *, 1 \% * * *)$

\begin{tabular}{|c|c|c|c|c|c|c|c|c|}
\hline \multirow[b]{3}{*}{ EXR flexibility } & \multicolumn{4}{|c|}{ Government size period $1970-2000$} & \multicolumn{4}{|c|}{ Government size period $1980-2000$} \\
\hline & \multicolumn{2}{|c|}{ OLS within } & \multicolumn{2}{|c|}{ OLS pooled } & \multicolumn{2}{|c|}{ OLS within } & \multicolumn{2}{|c|}{ OLS pooled } \\
\hline & $\begin{array}{l}-0.01 \\
(-0.21)\end{array}$ & $\begin{array}{c}-0.04 \\
(-0.63)\end{array}$ & $\begin{array}{c}0.00 \\
(0.10)\end{array}$ & $\begin{array}{c}0.01 \\
(0.15)\end{array}$ & $\begin{array}{l}-\mathbf{- 0 . 1 6 *} \\
(-1.86)\end{array}$ & $\begin{array}{l}-0.10 \\
(-1.31)\end{array}$ & $\begin{array}{c}0.02 \\
(0.46)\end{array}$ & $\begin{array}{c}0.01 \\
(0.21)\end{array}$ \\
\hline $\mathrm{G}(\mathrm{t}-1)$ & $\begin{array}{c}-\mathbf{- 0 . 6 7 * * *} \\
(-13.2)\end{array}$ & $\begin{array}{c}-\mathbf{0 . 7 0} * * * \\
(-11.1)\end{array}$ & $\begin{array}{c}-\mathbf{0 . 2 2} * * * \\
(-7.24)\end{array}$ & $\begin{array}{c}-\mathbf{0 . 2 1} * * * \\
(-6.54)\end{array}$ & $\begin{array}{c}-\mathbf{- 0 . 8 0 * * *} \\
(-11.4)\end{array}$ & $\begin{array}{c}-\mathbf{- 0 . 8 2} * * * \\
(-11.1)\end{array}$ & $\begin{array}{c}-\mathbf{0 . 2 2} * * * \\
(-6.76)\end{array}$ & $\begin{array}{c}-\mathbf{0 . 2 2} * * * \\
(-5.64)\end{array}$ \\
\hline Inflation (t-1) & & $\begin{array}{c}0.01 \\
(0.21)\end{array}$ & & $\begin{array}{c}0.01 \\
(0.30)\end{array}$ & & $\begin{array}{c}0.01 \\
(0.23)\end{array}$ & & $\begin{array}{c}0.01 \\
(0.29)\end{array}$ \\
\hline Growth $(\mathrm{t}-1)$ & & $\begin{array}{l}-\mathbf{2 . 4 4 *} \\
(-1.85)\end{array}$ & & $\begin{array}{l}-2.21 \\
(-1.50)\end{array}$ & & $\begin{array}{l}-\mathbf{2 . 8 8 * *} \\
(-2.14)\end{array}$ & & $\begin{array}{c}-2.25 \\
(-1.33)\end{array}$ \\
\hline Openness (t-1) & & $\begin{array}{c}0.47 \\
(1.01) \\
\end{array}$ & & $\begin{array}{c}-0.18 \\
(-1.41) \\
\end{array}$ & & $\begin{array}{c}0.54 \\
(1.21) \\
\end{array}$ & & $\begin{array}{c}-0.08 \\
(-0.53) \\
\end{array}$ \\
\hline POLCONV & & $\begin{array}{c}\mathbf{0 . 5 5 * *} \\
(2.00)\end{array}$ & & $\begin{array}{c}0.07 \\
(0.48)\end{array}$ & & $\begin{array}{l}\mathbf{0 . 7 6 * *} \\
(2.40)\end{array}$ & & $\begin{array}{c}0.11 \\
(0.72)\end{array}$ \\
\hline GOVCHANGES & & $\begin{array}{c}-\mathbf{0 . 1 6 * *} \\
(-2.52)\end{array}$ & & $\begin{array}{l}-0.08 \\
(-1.55)\end{array}$ & & $\begin{array}{c}-0.09 \\
(-1.26)\end{array}$ & & $\begin{array}{c}-0.02 \\
(-0.36)\end{array}$ \\
\hline Constant & & & $\begin{array}{c}0.72 * * * \\
(3.24)\end{array}$ & $\begin{array}{c}0.84 * * * \\
(3.47)\end{array}$ & & & $\begin{array}{c}1.03 * * * \\
(4.59)\end{array}$ & $\begin{array}{c}1.16^{* * *} \\
(3.98)\end{array}$ \\
\hline Time effects $\left(\mathrm{chi}^{2}\right)$ & $95.84 * * *$ & $43.67 * * *$ & $133.1 * * *$ & $91.57 * * *$ & $45.77 * * *$ & $24.14 * * *$ & $21.66^{* * *}$ & $15.01 * * *$ \\
\hline $\mathrm{R}^{2}$ & 0.46 & 0.47 & 0.26 & 0.23 & 0.47 & 0.52 & 0.16 & 0.16 \\
\hline Observations & 560 & 456 & 567 & 461 & 385 & 369 & 392 & 374 \\
\hline
\end{tabular}


Table 7. OECD sample panel estimates for government size (t-values in parentheses, significance levels: $10 \% *, 5 \% * *, 1 \% * * *)$

\begin{tabular}{|c|c|c|c|c|c|c|c|c|}
\hline \multirow[b]{3}{*}{ EXR flexibility } & \multicolumn{4}{|c|}{ Government size period $1970-2000$} & \multicolumn{4}{|c|}{ Government size period $1980-2000$} \\
\hline & \multicolumn{2}{|c|}{ OLS within } & \multicolumn{2}{|c|}{ OLS pooled } & \multicolumn{2}{|c|}{ OLS within } & \multicolumn{2}{|c|}{ OLS pooled } \\
\hline & $\begin{array}{c}0.08 \\
(1.04)\end{array}$ & $\begin{array}{c}-0.03 \\
(-0.35)\end{array}$ & $\begin{array}{c}\mathbf{0 . 1 4} * * \\
(2.21)\end{array}$ & $\begin{array}{c}0.11 \\
(1.63)\end{array}$ & $\begin{array}{c}-0.10 \\
(-0.99)\end{array}$ & $\begin{array}{c}-0.10 \\
(-1.08)\end{array}$ & $\begin{array}{l}\mathbf{0 . 1 3 *} \\
(1.69)\end{array}$ & $\begin{array}{c}0.11 \\
(1.48)\end{array}$ \\
\hline $\mathrm{G}(\mathrm{t}-1)$ & $\begin{array}{c}-\mathbf{- 0 . 4 6 * * *} \\
(-8.13)\end{array}$ & $\begin{array}{c}-\mathbf{0 . 4 5} * * * \\
(-8.39)\end{array}$ & $\begin{array}{c}-\mathbf{- 0 . 1 9} * * * \\
(-4.33)\end{array}$ & $\begin{array}{c}-\mathbf{0 . 1 6 * * *} \\
(-3.38)\end{array}$ & $\begin{array}{c}-\mathbf{0 . 5 5} * * * \\
(-15.0)\end{array}$ & $\begin{array}{c}-\mathbf{0 . 5 6} * * * \\
(-9.20)\end{array}$ & $\begin{array}{c}-\mathbf{0 . 1 5 * *} \\
(-2.49)\end{array}$ & $\begin{array}{r}-\mathbf{0 . 1 5} * * * \\
(-2.87)\end{array}$ \\
\hline Inflation $(\mathrm{t}-1)$ & & $\begin{array}{l}1.82 * \\
(1.95)\end{array}$ & & $\begin{array}{l}\text { 1.63* } \\
(1.89)\end{array}$ & & $\begin{array}{c}0.55 \\
(0.58)\end{array}$ & & $\begin{array}{c}2.10 * * \\
(2.34)\end{array}$ \\
\hline Growth (t-1) & & $\begin{array}{c}-7.85 * * \\
(-2.13)\end{array}$ & & $\begin{array}{c}-11.1 * * * \\
(-3.22)\end{array}$ & & $\begin{array}{l}-6.55 \\
(-1.17)\end{array}$ & & $\begin{array}{l}-7.49 * \\
(-1.82)\end{array}$ \\
\hline Openness (t-1) & & $\begin{array}{l}-1.96 \\
(-1.43) \\
\end{array}$ & & $\begin{array}{c}0.01 \\
(0.04) \\
\end{array}$ & & $\begin{array}{c}-1.78 \\
(-1.00) \\
\end{array}$ & & $\begin{array}{c}-0.07 \\
(-0.46) \\
\end{array}$ \\
\hline POLCONV & & $\begin{array}{c}2.29 * * * \\
(4.51)\end{array}$ & & $\begin{array}{l}\mathbf{0 . 6 0 *} \\
(1.71)\end{array}$ & & $\begin{array}{c}3.36 * * * \\
(5.26)\end{array}$ & & $\begin{array}{c}0.46 \\
(0.83)\end{array}$ \\
\hline GOVCHANGES & & $\begin{array}{l}-0.08 \\
(-1.07)\end{array}$ & & $\begin{array}{c}-0.07 \\
(-1.06)\end{array}$ & & $\begin{array}{c}-0.09 \\
(-1.02)\end{array}$ & & $\begin{array}{c}-0.06 \\
(-0.81)\end{array}$ \\
\hline Constant & & & $\begin{array}{c}0.03 \\
(0.11)\end{array}$ & $\begin{array}{l}-0.27 \\
(-0.67)\end{array}$ & & & $\begin{array}{c}0.33 \\
(1.28)\end{array}$ & $\begin{array}{c}0.12 \\
(0.24)\end{array}$ \\
\hline Time effects $\left(\mathrm{chi}^{2}\right)$ & $38.99 * * *$ & $16.37 * * *$ & $64.58 * * *$ & $59.99 * * *$ & $11.12 * *$ & 3.716 & $9.308 * *$ & $9.220 * *$ \\
\hline $\mathrm{R}^{2}$ & 0.50 & 0.52 & 0.37 & 0.35 & 0.36 & 0.45 & 0.14 & 0.22 \\
\hline Observations & 135 & 112 & 135 & 112 & 90 & 90 & 90 & 90 \\
\hline
\end{tabular}


Table 8 . World sample panel estimates for regulation (t-values in parentheses, significance levels: $10 \% *, 5 \% * *, 1 \% * * *)$

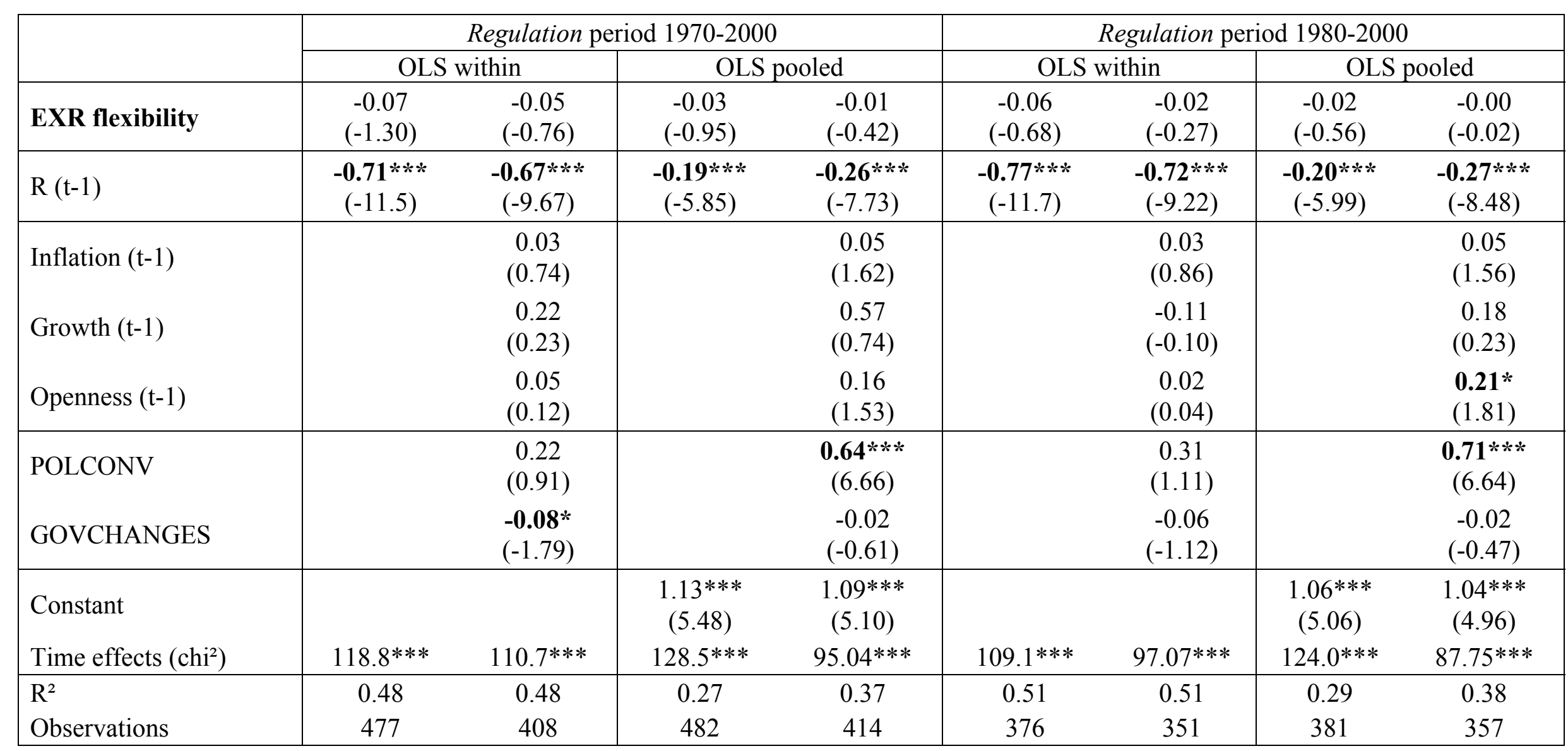


Table 9. OECD sample panel estimates for regulation (t-values in parentheses, significance levels: $10 \% *, 5 \% * *, 1 \% * * *)$

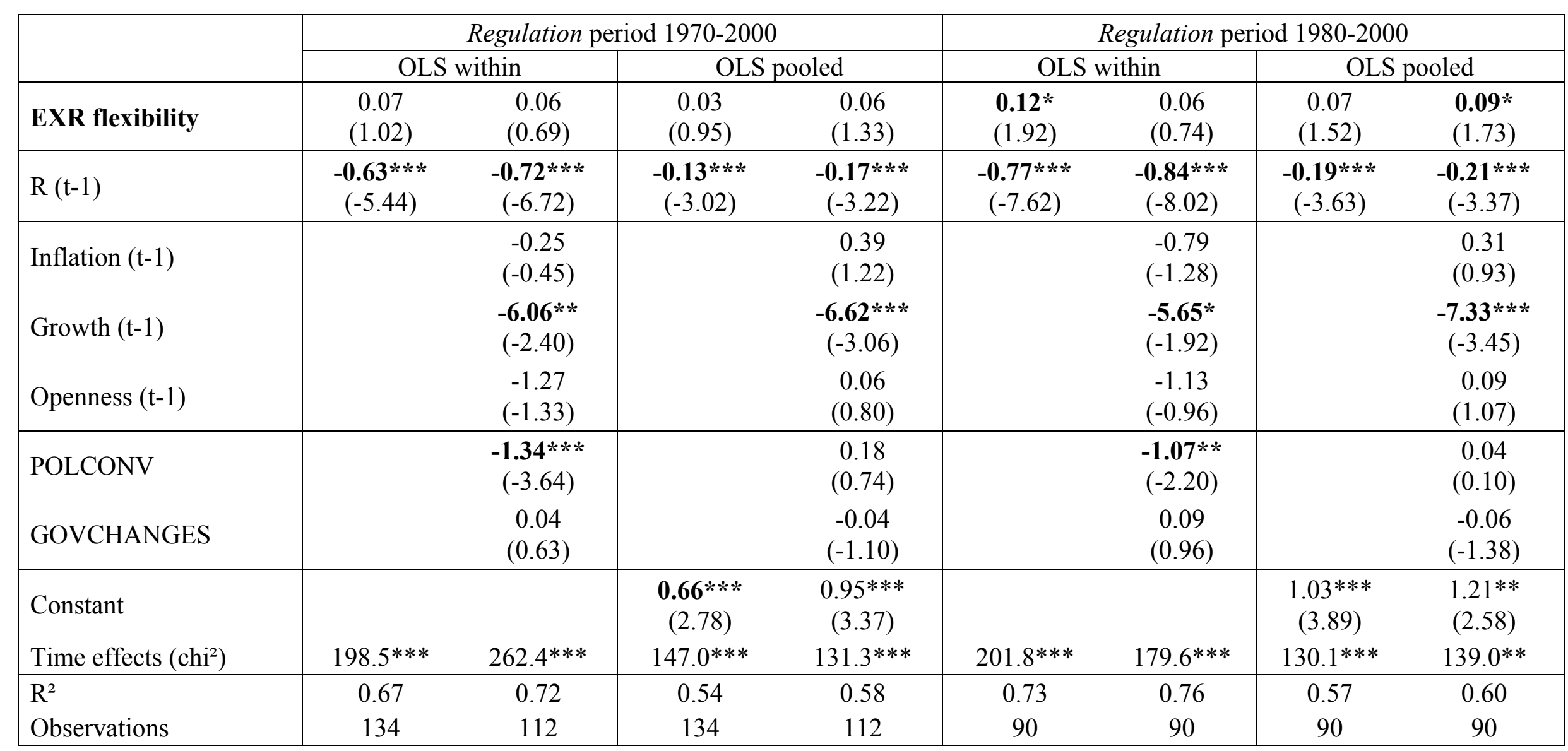


Table 10. Monetary commitment estimates for overall and financial sector reform

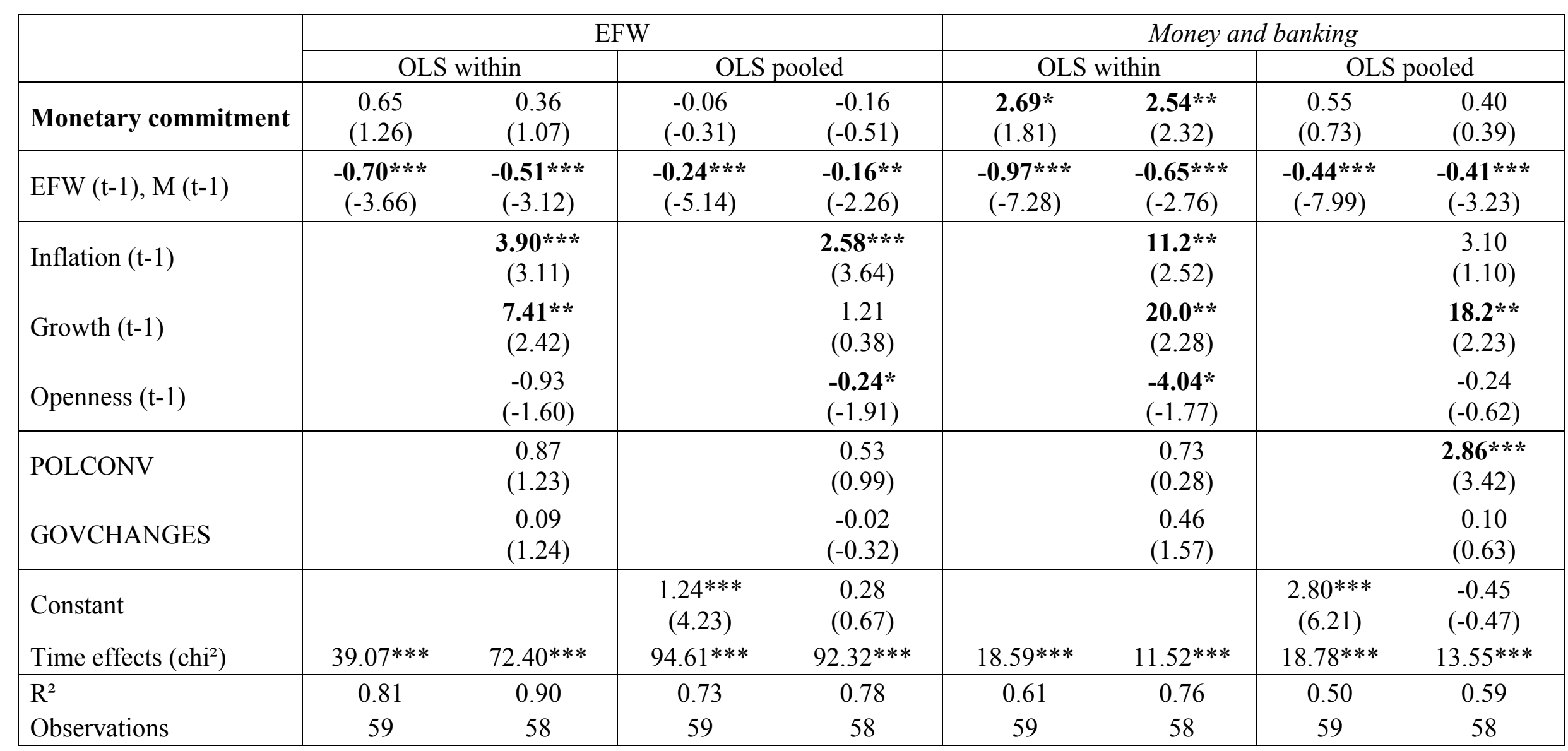


Table 11. Monetary commitment estimates for government sector and regulation reform

\begin{tabular}{|c|c|c|c|c|c|c|c|c|}
\hline \multirow[b]{3}{*}{ Monetary commitment } & \multicolumn{4}{|c|}{ Government size } & \multicolumn{4}{|c|}{ Market regulation } \\
\hline & \multicolumn{2}{|c|}{ OLS within } & \multicolumn{2}{|c|}{ OLS pooled } & \multicolumn{2}{|c|}{ OLS within } & \multicolumn{2}{|c|}{ OLS pooled } \\
\hline & $\begin{array}{c}-1.17 \\
(-1.31)\end{array}$ & $\begin{array}{l}-\mathbf{1 . 5 9} * \\
(-1.95)\end{array}$ & $\begin{array}{c}0.60 \\
(0.84)\end{array}$ & $\begin{array}{c}0.33 \\
(0.37) \\
\end{array}$ & $\begin{array}{l}\mathbf{0 . 7 3} * * \\
(2.16)\end{array}$ & $\begin{array}{c}2.54 * * \\
(2.32)\end{array}$ & $\begin{array}{c}0.36 \\
(1.30) \\
\end{array}$ & $\begin{array}{c}0.40 \\
(0.39)\end{array}$ \\
\hline $\mathrm{G}(\mathrm{t}-1), \mathrm{R}(\mathrm{t}-1)$ & $\begin{array}{c}-\mathbf{- 0 . 7 1} * * * \\
(-7.33)\end{array}$ & $\begin{array}{c}-\mathbf{0 . 6 1} * * * \\
(-5.73)\end{array}$ & $\begin{array}{c}-0.27 * * * \\
(-3.93)\end{array}$ & $\begin{array}{c}-\mathbf{- 0 . 2 3 * * *} \\
(-3.25)\end{array}$ & $\begin{array}{c}-\mathbf{- 0 . 8 4} * * * \\
(-5.89)\end{array}$ & $\begin{array}{c}-\mathbf{- 0 . 6 5 * * *} \\
(-2.76)\end{array}$ & $\begin{array}{l}-0.02 \\
(-0.31)\end{array}$ & $\begin{array}{c}-\mathbf{0 . 4 1} * * * * \\
(-3.23)\end{array}$ \\
\hline Inflation (t-1) & & $\begin{array}{l}\mathbf{4 . 8 4 *} \\
(1.81)\end{array}$ & & $\begin{array}{c}\mathbf{3 . 0 4} * * * \\
(3.55)\end{array}$ & & $\begin{array}{l}11.2 * * \\
(2.52)\end{array}$ & & $\begin{array}{c}3.10 \\
(1.10)\end{array}$ \\
\hline Growth (t-1) & & $\begin{array}{c}2.68 \\
(0.42)\end{array}$ & & $\begin{array}{c}-\mathbf{1 6 . 4} * * * \\
(-3.54)\end{array}$ & & $\begin{array}{l}20.0 * * \\
(2.28)\end{array}$ & & $\begin{array}{l}\mathbf{1 8 . 2 * * *} \\
(2.23)\end{array}$ \\
\hline Openness (t-1) & & $\begin{array}{c}-0.08 \\
(-0.10) \\
\end{array}$ & & $\begin{array}{c}-0.80 \\
(-1.59) \\
\end{array}$ & & $\begin{array}{l}-4.04 * \\
(-1.77) \\
\end{array}$ & & $\begin{array}{c}-0.24 \\
(-0.62) \\
\end{array}$ \\
\hline POLCONV & & $\begin{array}{l}\mathbf{3 . 3 0} * * \\
(2.09)\end{array}$ & & $\begin{array}{l}\mathbf{2 . 6 4 * *} \\
(2.24)\end{array}$ & & $\begin{array}{c}0.73 \\
(0.28)\end{array}$ & & $\begin{array}{c}\mathbf{2 . 8 6} * * * \\
(3.42)\end{array}$ \\
\hline GOVCHANGES & & $\begin{array}{c}0.11 \\
(0.49) \\
\end{array}$ & & $\begin{array}{c}-0.12 \\
(-0.71) \\
\end{array}$ & & $\begin{array}{c}0.46 \\
(1.57) \\
\end{array}$ & & $\begin{array}{c}0.10 \\
(0.63) \\
\end{array}$ \\
\hline Constant & & & $\begin{array}{l}-0.05 \\
(-0.12)\end{array}$ & $\begin{array}{c}-1.13 \\
(-1.02)\end{array}$ & & & $\begin{array}{c}0.14 \\
(0.32)\end{array}$ & $\begin{array}{c}-0.45 \\
(-0.47)\end{array}$ \\
\hline Time effects $\left(\mathrm{chi}^{2}\right)$ & $22.88 * * *$ & $46.26^{* * *}$ & $49.98 * * *$ & $22.59 * * *$ & $94.97 * * *$ & $11.52 * * *$ & $172.1 * * *$ & $13.55^{* * *}$ \\
\hline $\mathrm{R}^{2}$ & 0.82 & 0.88 & 0.55 & 0.68 & 0.87 & 0.76 & 0.70 & 0.59 \\
\hline Observations & 59 & 58 & 59 & 58 & 58 & 58 & 58 & 58 \\
\hline
\end{tabular}

